Amasya Illahiyat Dergisi - Amasya Theology Journal

ISSN 2667-7326 | e-ISSN 2667-6710

Aralık / December 2019, 13: 223-257

\title{
Namazdaki Dua Yerleriyle Şekillerinin Hadîslerle Tespiti ve Değerlendirilmesi
}

\section{Determination and Evaluation of Praying Places and Forms in Prayer with Hadîths}

\author{
Abdulvehhab Gözün \\ Dr. Öğr. Üyesi, Gümüşhane Üniversitesi, İlahiyat Fakültesi, \\ Hadîs Anabilim Dalı \\ Assistant Professor, Gümüşhane University, Faculty of Theology, \\ Deparment of Hadith \\ Gümüşhane/Turkey \\ abdulvehhab.gozun@gumushane.edu.tr \\ orcid.org/0000-0003-0333-4463
}

Makale Bilgisi / Article Information

Makale Türü / Article Types: Araştırma Makalesi / Research Article

Geliş Tarihi / Received: 5 Ağustos / August 2019

Kabul Tarihi / Accepted: 12 Eylül / September 2019

Yayın Tarihi / Published: 30 Aralık / December 2019

Yayın Sezonu / Pub. Date Season: Aralık / December

Sayı / Issue: 13 Sayfa / Pages: 223-257

Atıf / Cite as: Gözün, Abdulvehhab. "Namazdaki Dua Yerleriyle Şekillerinin Hadîslerle Tespiti ve Değerlendirilmesi [Determination and Evaluation of Praying Places and Forms in Prayer with Hadîths]". Amasya Illahiyat DergisiAmasya Theology Journal 13 (December 2019): 223-257.

https://doi.org/10.18498/amailad.601500.

İntihal / Plagiarism: Bu makale, en az iki hakem tarafından incelendi ve intihal içermediği teyit edildi. / This article has been reviewed by at least two referees and scanned via a plagiarism software.

Copyright $\odot$ Published by Amasya Üniversitesi, İlahiyat Fakültesi / Amasya University, Faculty of Theology, Amasya, 05100 Turkey. All rights reserved. https://dergipark.org.tr/amailad. 
224 | A. GÖZÜN / Namazdaki Dua Yerleriyle Şekillerinin Hadîslerle Tespiti ve Değerlendirilmesi

Determination and Evaluation of Praying Places and Forms in Prayer with Hadîths

Abstract

The prayer is one of the foundations that Islam was built on, which is also among the most important worships that symbolizes the physical and spiritual closeness of human being to Allah (swt). Therefore, such a worship gives an opportunity to human beings to make supplication to seek refuge from Allah (swt) as well asking for other needs.

However, many of the Muslims in our country follows Hanafi fiqh, therefore, in the fardh prayer before giving salaam people make certain supplications beside the supplication that surah al Fatiha has. The other supplications are being left after the prayer. However, these people are aware that firstly the moment of prostrating and the state of prayer are the closest moment to Allah (swt). In fact, praying in our country is being expressed as standing in front of Allah (swt) in metaphorical sense.

Only, considering these facts, it shows us the importance of the supplication during the prayer as well as the chance of acceptance by Allah (swt). Therefore, in this study, the subject of supplication was examined during the prayer to explain how and where to make the supplication in the light of the hadith of Prophet Muhammad (pbuh).

Therefore, it is aimed to reveal where and how to make dua during the prayer according to Sunneh. It is concluded that the supplication can be made during the prayer not only ka'de-i ahîret which widely known among the people but also q1yam, ruku, sajdah as well. The supplication of qunut which is made before going to the ruku in the vitr prayer and after getting up from the ruku in the morning prayer thought to be a subject to study therefore, it is taken into research.

\section{Summary}

It is inevitable that the content of salaah which is the second of the five pillars of Islam, includes supplication that symbolizes the need for the creator and seeking refuge from him. However, the way of performing salaah, where and how to make supplication in the salaah can be learned from the practices of the Prophet (pbuh), who was also held accountable for these worships, like the other pillars of the Islam such as fasting, hajj and zakat.

As a result of the researches that conducted on the subject of valid stories, it was determined that supplication was performed in seven places during the salaah. The first of the supplication comes after the iftitâh takbir. As a matter of fact, it was stated that the Prophet (pbuh) made supplication before reciting 
quran when he began to salaah. Therefore, the first supplication is made in salaah after the iftitâh takbir. This supplication is called the "supplication of Istiftah".

From some hadiths, it is understood that the second place of supplication in salaah is after The Fâtiha which is the second half of the qiyam. As a matter of fact, in some stories, it was stated that Rasûlullah (pbuh) when he was performing nafile salaah at night, he also made supplication while reading zamm-1 sûre in salaah. Only some of the Hanbalis and Shafiis have pointed out that this supplication is good deed when it is performed in night prayers. In the compulsory prayers, we have not found any evidence that the Prophet (pbuh) has done similarly. Therefore, according to research, the figh scholars did not touch on this issue.

As far as it is concerned, the third of the supplication place in salaah is the rukû. As a matter of fact, in some stories, while Prophet performing salaah, he also made supplication beside making usual supplication in rukuh. Some scholars, such as Shafiî and Bukhârî, have said that it is permissible to make supplication in the rukuh. Others, such as Malikis have argued that this is mekrûh. In general, according to the Hanafis and the Hanbalis, it is enough to do rukuh supplication do praising Allah in the rukuh. It is not appropriate to make other supplication.

From the conducted researches, it has been determined that the fourth place of supplication in salaah is the state of standing (when the person straighten up after the rukuh). Because in some stories, it was stated that when the Prophet (pbuh) raised his head from the rukuh, he also made a number of supplications. Some Hanbali and Shafi'i scholars have shown some of the relevant stories as evidence to indicate that it is good deed when such supplication is made. The Hanafis and The Malikis, on the other hand, have generally referred such supplication to the tahaccud salaahs and the nafila salaahs. Therefore, according to them, when the compulsory salaahs performed with congregation, it is enough to do rukuh supplication do praising Allah in the rukuh.

The fifth supplication place in salaah is the state of prostration. It is possible to divide the relevant stories of the Prophet (pbuh) into two parts. The first one is the stories to encourage prayers to make supplication in the state of prostration. And the second part is the prophet's (pbuh) supplication that he made it in the state of prostration himself. In this regard, the fikh scholars have different opinions. However, there are many hadith relevant to this subject and it would be more accurate to say that this is sunnah on all salaahs.

According to some stories, the sixth of the places where supplication can be made is between two prostration. The malikis have said that this supplication is 
226 | A. GÖZÜN / Namazdaki Dua Yerleriyle Şekillerinin Hadîslerle Tespiti ve Değerlendirilmesi permissible it is not makruh. The Shafiis have stated that they are not only permissible, but also good deeds when it is made. As for the Hanafis, they said there was no sunnah invocation here. The situation is different compared to the Hanbali. According to them, making this supplication once between the two state of prostration is wacib; It is good deeds to say it three times, such as supplication that made in the state of prostration and rukuh.

According to the researches, the place where making supplication in all salaahs are after the second sitting. After the first sitting there is no supplication. However, according to the Hanafis and Hanbalis, the supplication should not be similar to supplicition's word that people use to make supplication. According to Maliki and Shafî̂, me'sur supplication are better but there is no such limitation.

Keywords: Hadith, Prayer, Supplication, Prostration, Sîga.

Öz

\section{Namazdaki Dua Yerleriyle Şekillerinin Hadîslerle Tespiti ve Değerlendirilmesi}

İslâm'ın üzerine bina edildiği temellerden biri olan namaz, insanın fiziksel ve ruhsal anlamda Allah'a (c.c.) kulluğunu sembolize eden en önemli ibadetlerdendir. Dolayısıyla böyle bir ibadetin, ubûdiyetin olmazsa olmazlarından acziyet, yalvarış, yakarış, ihtiyaç ve iltica gibi hususları ifade eden duayı içinde barındırması tabiî olan bir durumdur.

Bununla birlikte ülkemizdeki Müslümanların çoğu namaz içerisinde, özellikle Hanefî fıkıh ve ilmihal kitaplarındaki farz namazların kılınış şekliyle ilgili bilgilere paralel bir biçimde ve zamanla oluşan teamüle uygun olarak, Fâtiha'nın içerdiği dua dışında selam vermeden önce düzenli olarak okudukları belli başlı dualarla yetinmektedirler. Yapmak istedikleri farklı duaları ise namaz sonrasına birakmaktadırlar. Hâlbuki bu insanlar, başta secde konumu olmak üzere kişinin Allah'a (c.c.) manevî anlamda en yakın olduğu durumun namaz hali olduğunun farkındadırlar. Hatta ülkemizde namaz kılmak, mecâzî anlamda "Allah'ın (c.c.) huzuruna çıkmak" ifadesiyle betimlenir.

Sadece bu gerçekten hareket edilse bile namaz içerisinde duanın ne kadar önemli olduğu ve kabule daha şâyân olacağı anlaşılmaktadır. Binaenaleyh bu çalışmada namaz esnasında nerelerde ve nasıl dua edileceği konusu, diğer tüm ibadetler gibi namaz ibadetinin de ancak kendisinden öğrenilebileceği $\mathrm{Hz}$. Peygamber'in (s.a.v.) hadîsleri ışı̆̆ında ele alınıp incelenmiştir.

Böylece araştırmada sünnete göre namaz içerisinde nerelerde ve nasıl dua yapılabileceğinin ortaya çıkarılması amaçlanmıştır. Neticede yaygın olarak halk tarafından bilinenin ve uygulanılanın aksine sadece ka'de-i ahîrede değil 

kıyam, rükû, itidâl ve secde gibi diğer bazı hallerde de farklı sîgalarla namazda dua yapılabileceği sonucuna ulaşılmıştır. Vitir namazında rükûya gitmeden önce; sabah namazında da rükûdan kalkılınca yapılan kunût duası ise, müstakil bir çalışmanın konusu olduğu düşünüldüğünden araştırmanın kapsamına alınmamıştır.

Anahtar Kelimeler: Hadîs, Namaz, Dua, Secde, Sîga.

\section{Giriş}

Sözlükteki anlamlarından biri de dua olan salât ${ }^{1}$ kelimesinin dindeki ilk akla gelen ıstılâhî manası bilindiği üzere namaz ibadetidir. Nitekim âyetlerde ve hadîslerde bu sözcük daha çok bu anlamıla kullanılmaktadır. Bununla birlikte hem "Dua ibadetin kendisidir²/özüdür." buyuran Hz. Peygamber'in (s.a.v) sözüne uygun olarak hem de vech-i tesmiye kabîlinden bu sözcügün lugavî manasıyla irtibatlandırılarak İslâm'ın beş rüknünden ikincisi olan namaz ibadetinin muhtevasında duanın yer alması kaçınılmaz bir gerçekliktir.

Ancak namazın kılınış şekli Resûlullah'ın (s.a.v.) "Benim nasıl namaz kıldığımı görüyorsanız siz de öyle kılın."4 sözünden de anlaşıldığ 1 gibi tevkîfî olduğundan namazın neresinde ve nasıl dua edileceği şüphesiz sadece Hz. Peygamber'in (s.a.v.) sünnetinden öğrenilebilir.

1 Ebû Nasr İsmail b. Hammâd el-Fârâbî el-Cevherî, "Slv", Tâcu'l-luğa ve sihâhu'larabiyye, thk. Ahmed Abdulğafûr Attâr (Beyrut: Dâru'l-ilm li'l-melâyîn, 1407/1987), 6: 2402; Ebü'l-Fadl Cemâlüddîn Muhammed b. Mükerrem b. Ali el-Ensârî er-Ruveyfiî el-İfrîkî el-Misrî İbn Manzûr, “Slv”, Lisânü'l-arab (Beyrut: Dâru Sâdir, 1414), 14: 465; Ebü'l-Feyz Mürtezâ Muhammed b. Muhammed b. Abdirrezzâk el-Hüseynî ezZebîdî, "Slv", Tâcu'l-arûs min cevâhiri'l-kâmûs (b.y.: Dâru'l-hidâye, ts.), 38: 437.

2 Ebû Dâvûd, "Vitir", 23; Tirmizî, "Tefsîru'l-Kur'ân”, 1; İbn Mâce, "Dua”, 1; Ebû Dâvûd Süleyman b. Dâvûd b. Cârûd el-Basrî et-Tayâlisî, Müsned, thk. Muhammed b. Abdilmuhsin et-Türkî (Mısır: Dâru Hecer, 1419/1999), 2: 147. Tirmizî hadîsin “hasensahîh" olduğunu ifade etmiştir.

3 Tirmizi, "Deavât”, 1; Ebü'l-Kâsım Süleyman b. Ahmed b. Eyyüb el-Lahmî eş-Şâmî etTaberânî, ed-Duâ, thk. Mustafa Abdulkâdir Atâ (Beyrut: Dâru'l-kütübi'l-ilmiyye, 1413), 1, 24. Tirmizî hadîsin bu vecihten "ğarîb" olduğunu söylemiş̧tir.

4 Ebû Abdillah Muhammed b. İdris el-Kuraşî eş-Şâfiî, Müsned (Beyrut: Dâru'l-kütübi'lilmiyye, 1400), 1: 55; Buhârî, “Ezân”, 18; Dârimî, "Salât", 42; Ebû Bekir Muhammed b. İshak İbn Huzeyme en-Neysâbûrî, Sahîh, thk. Muhammed Mustafa el-Azamî (Beyrut: el-Mektebü'l-islâmî, ts.), 1: 206; Ebû Hâtim Muhammed b. Hibbân b. Ahmed İbn Hibbân ed-Dârimî el-Büstî, Sahîh, thk. Şuayb el-Arnavut (Beyrut: Müessesetü'r-risâle, 1414/1993), 4: 541. 
228 | A. GÖZÜN / Namazdaki Dua Yerleriyle Şekillerinin Hadîslerle Tespiti ve Değerlendirilmesi Böyle olmakla birlikte fakîhler arasında diğer birçok konuda olduğu gibi bu hususta da ictihadda ihtilafa sebep olan değişik nedenlerle görüş farklılığı bulunmaktadır.

$\mathrm{Bu}$ çalışmada ise ilgili rivâyetler esas alınarak hadîsler ışı̆̆ında namazdaki dua yerleri ve şekilleri incelenmeye çalışılacaktır. Bu amaçla kütüb-i tis'a başta olmak üzere temel hadîs kaynaklarına ve birtakım hadîs şerlerine müracaat edilecektir. İşin mezhepler arasında ihtilaf içeren fikhî boyutuna ise sadece mezhep tercihleri zikredilerek kısaca işaret edilecektir. Mezkûr tercihlerin detaylı delillerine ise değinilmeyecektir. Bunun için de bazı fıkıh kaynaklarından istifade edilecektir. Ayrıca görüldüğü kadarıyla özel olarak bu mesele hakkında müstakil ve güncel bir çalışma yapılmamıştır. Öncelikle konuyla ilgili vârid olan rivâyetler üzerinden yapılan araştırmalar sonucunda namaz içerisinde yedi yerde ${ }^{5}$ dua yapıldığ 1 tespit edilmiştir.

\section{1. İftitâh Tekbirinden Sonra Yapılan Dua (İstiftâh Duası)}

İlgili rivâyetlerde, Hz. Peygamber'in (s.a.v.) tekbirle namaza başladığında kıraattan önce dua ettiği sabit olmuştur. Dolayısıyla namaz içerisinde ilk dua iftitâh tekbîrinden sonra yapılır. Burada okunan duaya fakîhler "İstiftâh Duası" adını vermişlerdir. Âlimlerin ekseriyeti, bu duanın mezkûr yerde yapılmasının sünnet olduğunda ittifak halindedir. ${ }^{6}$ Ancak Mâlikîlerin çoğunluğu, bu duanın namaza

5 İbn Hacer (ö. 852/1449), kunûtla beraber kıyamda yapılan duayı istisnâ ederek namazda altı yerde dua edilebileceğini ifade etmiştir. (Ebü'l-Fadl Ahmed b. Ali İbn Hacer el-Askalânî, Fethu'l-bârî şerhu Sahîhi'l-Buhârî (Beyrut: Dâru'l-ma'rife, 1379), 11: 132.) Ancak çalışmada kıyamın da namazın rükunlarından olduğu gerçeğinden yola çıkılarak dua yerlerinin yedi olması tercih edilmiştir. Kunût ise ya kıyamda ya da rükûdan kalkıldığında yapılan dua olduğu için ayrı bir yer olarak değerlendirilmemiştir. İbn Kayyim el-Cevziyye (ö. 751/1350) ise çalışmada olduğu gibi namazdaki dua yerlerini yedi yer olarak taksim etse de o, vitirde kıraattan sonra yahut sabah namazında rükûdan kalkıldığında okunan kunût duasını ayrı yer olarak değerlendirmiştir. (Şemsüddîn Muhammed b. Ebî Bekir b. Eyyüb İbn Kayyim elCevziyye, Zâdu'l-meâd fî hedyi hayri'l-ibâd (Beyrut: Müessesetü'r-risâle, 1415/1994), 1: 249.) Hâlbuki araştırmada kıraat esnasında kıyamda yapılabilen dua kast edilerek "Fâtiha'dan Sonra" başlığı ilave edilmiş ve namazdaki dua yerleri buna göre yedi yer olarak taksim edilmiştir.

6 Ebû Abdillah Ekmelüddîn Muhammed b. Muhammed b. Mahmûd er-Rûmî elBâbertî, el-İnâyetü şerhu'l-Hidâye (Beyrut: Dâru'l-fikr, ts.), 1: 309; Ebû Muhammed Bedruddîn Mahmud b. Ahmed b. Musa el-Hanefî el-Aynî, el-Binâye şerhu'l-hidâye (Beyrut: Dâru'l-kütübi'l-ilmiyye, 1420/2000), 2: 184; Ebû Abdillah Muhammed b. Ali 
başlamadan önce yapılacağını, iftitâh tekbirinden sonra ise bu duayı yapmanın mekruh olduğunu ve direkt kıraatle başlanılması gerektiğini dile getirmişlerdir. ${ }^{7}$

Nitekim İbnü'l-Arabî (ö. 543/1148), İmam Mâlik'in (ö. 179/795) şöyle dediğini kaydetmektedir:

"Vâcib olan, önce tekbîr sonra kıraattir. Zira tekbir ile kıraatin arasında Hz. Peygamber (s.a.v.) sükût etmeye devam etseydi bu bize gizli kalmazdı ve Medine ahâlisi bunu bize ayan beyan ve amel olarak naklederdi. Dolayısıyla Resûlullah'ın (s.a.v.) bu duayı bir ara yapıp daha sonra ümmetine tahfîf için terk etmiş olma ihtimali sözkonusudur." 8

Bununla birlikte Mâlik'ten kıraatten önce bu duayı yapmanın mendûb olduğu görüşü de nakledilmiştir. ${ }^{9}$ Ayrıca Mâlikîlerden Lahmî de (ö. 478/1086) mezhebinin genel görüşünü zikrettikten sonra cevazın daha güzel olduğunu ifade etmiştir. ${ }^{10}$

İlgili rivâyetler incelendiğinde bu duanın altı farklı sîgası tespit edilmiştir. Genel olarak fakîhler bu sîgalardan herbirinin istiftâh duası olarak okunabileceğini söylemekle beraber evlâ olanı hakkında ihtilaf etmişlerdir. ${ }^{11}$ Mezkûr sîgalar şunlardır:

1. Sîga: Bu sîga istiftâh duası olarak en meşhur olan sîgadır.12 Bununla ilgili rivâyetler merfû ve mevkûf olmak üzere iki kısımdır.

b. Ömer et-Temîmî el-Mâlikî el-Mâzerî, Şerhu't-telkîn, thk. Muhammed Muhtar esSelâmî (Dâru'l-ğarbi'l-islâmî, 2008), 1: 573.

7 Ebû Muhammed Abdulvehhâb b. Ali b. Nasr el-Bağdâdî el-Mâlikî es-Sa'lebî, elMe'ûne alâ mezhebi âlimi'l-Medîne, thk. Humeyş Abdulhakk (Mekke: el-Mektebetü'tticâriyye, ts.), 1: 216; Ebû Abdillah Muhammed b. Ahmed b. Muhammed Uleyş elMâlikî, Menhu'l-celîl şerhu muhtasari Halîl (Beyrut: Dâru'l-fikr, 1409/1989), 1: 266; Ebü't-Tâhir İbrahim b. Abdissamed b. Beşîr et-Tenûhî el-Mehdivî, et-Tenbîh alâ mebâdii't-tevcîh, thk. Muhammed Belhasân (Beyrut: Dâru İbn Hazm, 1428/2007), 1: 406.

8 Ebû Bekir Kâdî Muhammed b. Abdillah el-Meâfirî İbnü'l-Arabî el-İşbîlî, el-Mesâlik fî şerhi Muvattâ Mâlik (b.y.: Dâru'l-garbi'l-islâmî, 1428/2007), 2: 364.

$9 \quad$ Sa'lebî, el-Me'ûne 1: 216.

10 Ebü'l-Hasan Ali b. Muhammed er-Rib'î el-Lahmî, et-Tebsıra, thk. Ahmed Abdulkerîm Necîb (Katar: Vizâratü'l-evkâf ve'ş-şuûni'l-islâmiyye, 1432/2011), 1: 253.

11 Ebû Zekeriyya Muhyiddîn Yahya b. Şeref en-Nevevî, el-Mecmû şerhu'l-Mühezzeb (Beyrut: Dâru'l-fikr, ts.), 3: 321; Sadruddîn Ali b. Ali b. Ebi'l-İzz el-Hanefî, et-Tenbîh alâ müşkilâti'l-Hidâye, thk. Abdulhakîm b. Muhammed Şâkir - Enver Salih Ebû Zeyd (Suûdiyye: Mektebetü'r-rüşd, 1424/2003), 2: 533.'

12 Bundan dolayı aşağıda bu sîgayla ilgili rivâyetlerin tahricine detaylı olarak yer verilecektir. 
230 | A. GÖZÜN / Namazdaki Dua Yerleriyle Şekillerinin Hadîslerle Tespiti ve Değerlendirilmesi Sahâbeden Hz. Âişe, Ebû Saîd el-Hudrî, Hz. Ömer, Abdullah b. Ömer, Abdullah b. Mes'ûd, Câbir b. Abdullah ve Enes b. Mâlik'ten merfû olarak rivâyet edildiğine göre Hz. Peygamber (s.a.v.) namaza başladığında şunu söylerdi:

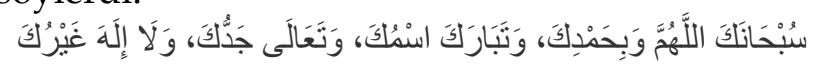

"Allah'ım! Sana hamd etmekle birlikte seni tesbih ederim. Senin adın mübarek oldu. Şanın yüce oldu ve senden başka ilah yoktur."13

Mevkûf olarak rivâyet edilişine gelince başta Hz. Ömer olmak üzere Hz. Ebû Bekir, Hz. Osman, İbn Mes'ûd gibi sahâbîlerden iftitâh

13 Hz. Âişe rivâyeti için bk. Ebû Dâvûd, "Salât", 120; Tirmizî, "Salât", 65; İbn Huzeyme, Sahîh, 1: 239. Ebû Saîd el-Hudrî rivâyeti için bk. Ebû Dâvûd, "Salât", 120; Tirmizî, "Salât", 65; Nesâî, "İftitâh", 18; İbn Mâce, "İkâmetü's-salât", 1; Ahmed b. Hanbel, Müsned, 3: 69. Hz. Ömer rivâyeti için bk. Ebü'l-Hasan Ali b. Ömer b. Ahmed elBağdâdî ed-Dârekutnî, Sünen, thk. Şuayb el-Arnavut vdğr. (Beyrut: Müessesetü'rrisâle, 1424/2004), 2: 60. İbn Ömer rivâyeti için bk. Taberânî, ed-Duâ, 1: 171. Abdillah b. Mes'ûd rivâyeti için bk. Ebü'l-Kâsım Süleyman b. Ahmed b. Eyyüb el-Lahmî eşŞâmî et-Taberânî, el-Mu'cemu'l-evsat, thk. Târık b. İvadillah b. Muhammed (Kahire: Dâru'l-haremeyn, ts.), 1: 305. Hz. Enes rivâyeti için bk. Taberânî, el-Mu'cemu'l-evsat, 3: 242; Dârekutnî, Sünen, 2: 62. Câbir b. Abdillah rivâyeti için bk. Ebû Bekir Ahmed b. Hüseyin b. Ali b. Musa el-Horasânî el-Beyhakî, es-Sünenü'l-kübrâ, thk. Muhammed Abdulkâdir Atâ (Beyrut: Dâru'l-kütübi'l-ilmiyye, 1424/2003), 2: 52. Oğlunun zikrettiğine göre Ebû Hâtim (ö. 277/890), Dârekutnî'nin isnadında yer alan Hüseyin b. Ali b. Esved el-İclî'nin yalancı olduğunu ima ederek mezkûr rivâyet hakkında "Bu hadîs yalandır. Aslı yoktur." demiştir. (Bk. Ebû Muhammed Abdurrahman b. Muhammed b. İdris el-Hanzalî er-Râzî İbn Ebî Hâtim, el-İlel, thk. Sa'd b. Abdillah elHamîd - Hâlid b. Abdirrahmân el-Cerîsî (Riyad: Matâbiu'l-Humeyzî, 1427/2006), 2: 283.) Ancak Elbânî, Ebû Hâtim'in bu sözünü eleştirerek şunu dile getirmiştir: “Oğlunun ifadesiyle Ebû Hâtim'in bizzat kendisi bu râviden rivâyette bulunmuş, nasıl bir râvi olduğu kendisine sorulduğunda da onu "sadûk" olarak nitelendirmiştir. (Bk. Ebû Muhammed Abdurrahman b. Muhammed b. İdris elHanzalî er-Râzî İbn Ebî Hâtim, el-Cerh ve'ta'dîl (Beyrut: Dâru ihyâi't-türâsi'l-arabî, 1271/1952), 3: 56.) Buna rağmen Ebû Hâtim'in mezkûr rivâyet hakkında, "Bu hadîs yalandır. Aslı yoktur." demesinin nasıl mümkün olduğunu vallahi bilmiyorum, bir gün bileceğimi de sanmiyorum. Üstelik rivâyetin metninde münker bir şey bulunmamaktadır. Ayrıca rivâyetin, sapasağlam bir sahih hadîs olduğunu gösteren başka tarikleri ve şahitleri mevcut olup sihhatini teyid eden selefin ameli de ortadadır." (Ebû Abdirrahmân Muhammed Nâsıruddîn b. el-Hâc Nuh b. Necâtî b. Âdem el-Elbânî, Silsiletü'l-ehâdîsi's-sahîha ve şey'un min fikhihâ ve fevâidihâ (Riyad: Mektebetü'l-maârif, 1415-1422/1995-2002), 6: 1256.) 
tekbirinden sonra bu duayı okudukları rivâyet edilmiştir. ${ }^{14}$ Hatta Hz. Ömer'in, kendisine namaza nasıl başlanılacağını soran insanlara uygulamalı olarak öğretmek için tekbirden sonra bu duayı sesli yaptığı da rivâyet edilmiştir. ${ }^{15}$

Âlimlerin çoğunluğu bu sîgayı tercih etmişlerdir. Nitekim Aynî́nin (ö. 855/1451) kaydettiğine göre Hz. Ebû Bekir, Hz. Ömer, Hz. Osman, İbn Mes'ûd, Nehaî (ö. 96/714), İmâm Muhammed (ö. 189/805), Ahmed b. Hanbel (ö. 241/855) ve İshak da (ö. 238/853) bu görüştedir. Ancak Ebû Yusuf (ö. 182/798), namaz k1lanin mezkûr duaya (tesbih) aşağıdaki وَجَّهنتُ وَجْهَيَ diye başlayan duayı da (tevcîh) (من المسلمين'e kadar) ekleyebileceğini ifade etmiştir. ${ }^{16}$ Bazı Hanefîler ise tevcîh duasının sadece teheccüd namazında eklenebileceğini dile getirerek bu duayla ilgili rivâyetleri gece namazına hamletmişlerdir. ${ }^{17}$

Kâsânî (ö. 587/1191) gibi bazı Hanefî fakîhler de zikredilen duanın dışında bazı rivâyetlerde vârid olan sîgaların nafile namazlar için geçerli olduğunu, farz namazlarda ise sadece meşhur olan yukarıdaki duanın yapılması gerektiğini dile getirmişlerdir. ${ }^{18}$ Hanbelîlerin görüşü ise, istiftâh duası olarak evlâ olanın mezkûr sîganın okunması olsa bile farz yahut nafile namaz ayrımı olmaksızın diğer sîgaların da okunmasının

14 Ebû Abdillah Muhammed b. Abdillah b. Muhammed el-Hâkim en-Neysâbûrî, elMüstedrek, thk. Mustafa Abdulkâdir Atâ (Beyrut: Dâru'l-kütübi'l-ilmiyye, 1411/1990), 1: 361; Ebû Bekir Abdurrezzâk b. Hemmâm b. Nâfi' el-Himyerî el-Yemânî es-San'ânî, Musannef, thk. Habîburrahmân el-Azamî (Beyrut: el-Mektebü'l-islâmî, 1403), 2: 75; Ebû Bekir Abdullah b. Muhammed b. İbrahim İbn Ebî Şeybe el-Absî, Musannef, thk. Kemal Yusuf el-Hût (Riyad: Mektebetü'r-rüşd, 1409), 1: 208-209; Taberânî, elMu'cemu'l-kebîr, 9: 262; Dârekutnî, Sünen, 2: 61; Beyhakî, es-Sünenü'l-kübrâ, 2: 52.

15 Ebû Yusuf Yakub b. İbrahim b. Habîb el-Ensârî, el-Âsâr, thk. Ebü'l-vefâ el-Afganî (Beyrut: Dâru'l-kütübi'l-ilmiyye, ts.), 1: 21; Ebû Abdillah Muhammed b. Hasan eşŞeybânî, el-Âsâr, thk. Ebü'l-Vefâ el-Afganî (Beyrut: Dâru'l-kütübi'l-ilmiyye, ts.), 1: 122.

16 Ebû Bekir Alâuddîn Muhammed b. Ahmed b. Ebî Ahmed b. Hanbel es-Semerkandî, Tuhfetü'l-fukahâ (Beyrut: Dâru'l-kütübi'l-ilmiyye, 1414/1994), 1: 127; Alâuddîn Ebû Bekir b. Mes'ûd b. Ahmed el-Kâsânî, Bedâyiu's-sanâyi' fi tertîbi'ş-şerâyi' (Beyrut: Dâru'l-kütübi'l-ilmiyye, 1406/1986), 1: 202; Aynî, el-Binâye, 2: 184.

17 Ahmed b. Muhammed b. İsmail el-Hanefî et-Tahtâvî, Hâşiyetü't-Tahtâvî alâ Merâkı'lfelâh, thk. Muhammed Abdulazîz el-Hâlidî (Beyrut: Dâru'l-kütübi'l-ilmiyye, 1418/1997), 1: 281.

18 Kâsânî, Bedâyi', 1: 202. Ayrıca bk. Halîl Ahmed b. Hanbel es-Sehârenpûrî, Bezlü'lmechûd fî halli Süneni Eb̂̀ Dâvîd (Hindistan: Merkezü'ş-Şeyh Ebi'l-Hasan en-Nedvî li'l-buhûs ve'd-dirâsâti'l-islâmiyye, 1427/2006), 4: 117. 
232 | A. GÖZÜN / Namazdaki Dua Yerleriyle Şekillerinin Hadîslerle Tespiti ve Değerlendirilmesi caiz ve güzel olduğudur. ${ }^{19}$ Şunu da ifade etmek gerekir ki; bu sîga, her ne kadar Allah'tan (c.c.) bir istek içermeyip tesbih, hamd, tâzim ve tehlîlden ibaret olsa da âlimlerin ekseriyeti tarafından tercih edildiği ve istiftâh duası diye isimlendirildiği için çalışmada dua sîgaları kategorisinde değerlendirilmiştir.

Ayrıca Hz. Âişe'nin rivâyetinde dua bu kadar olmakla beraber Ebû Saîd el-Hudrî'den nakledilen diğer rivâyette ise gece namazında Resûlullah'1n (s.a.v.) daha sonra üçer defa الله أكبر كبيرا ve لا إله إلا الله dedikten sonra şu istiâzeyi yaptı̆̆ı da yer almaktadır:

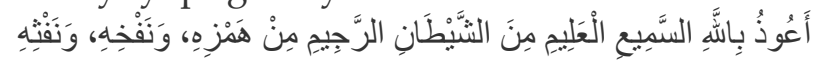

“Taşlanmış (kovulmuş) şeytandan; dürtmesinden (vesvesesinden), üfürmesinden ve tükürmesinden (her şeyi) bilen ve işiten Allah'a (c.c.) siğınırım."20 Tirmizî̀nin naklettiği varyantta ise sadece “Bir defa الله أكبر كبير dedikten sonra mezkûr sîgayla istiâze yapard1." diye geçmektedir. ${ }^{21}$ Ancak bu ilavelerin gece namazında olduğu rivâyetlerde açıkça ifade edilmektedir. Dolayısıyla tüm namazlarda okunması sözkonusu değildir.

2. Sîga: Ali b. Ebî Tâlib’ten rivâyet edildiğine göre, Hz. Peygamber (s.a.v.) namaz için kıyama durduğunda (tekbirden sonra) şu duayı yapard1:

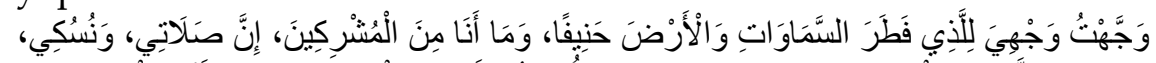

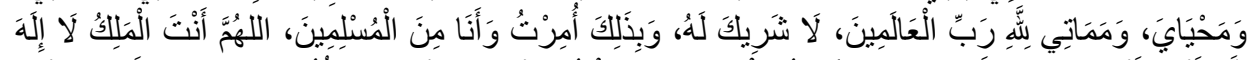

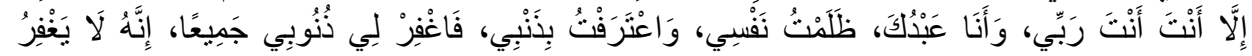

19 Ebû Muhammed Muvaffakuddîn Abdullah b. Ahmed b. Muhammed el-Cemâilî elMakdisî İbn Kudâme, el-Kâfí fí fikhi'l-İmam Ahmed b. Hanbel (Beyrut: Dâru'l-kütübi'lilmiyye, 1414/1994), 1: 244; a.mlf., el-Muğn̂̂ (Mektebetü'l-Kahire, 1388/1968), 1: 342; Ebü'l-Abbâs Takıyyüddîn Ahmed b. Abdilhalîm b. Abdisselâm el-Harrânî edDımaşkî İbn Teymiyye, Şerhu'l-Umde, thk. Abdulazîz b. Ahmed el-Müşeykıh (Riyad: Dâru'l-âsıme, 1429/2008), 1: 79.

20 Ebû Dâvûd, "Salât", 119; Ahmed b. Hanbel, Müsned, 3: 50; İbn Huzeyme, Sahîh, 1: 238. Ancak İbn Huzeyme rivâyetteki duayla ilgili şunu dile getirmiştir: “Ne eski zamanlarda ne de yeni dönemlerde âlimlerden namazın başında böyle bir dua yaptıkları işitilmiştir."

21 Tirmizî̀, "Salât", 65. İbn Receb'in (ö. 795/1393) ifade ettiğine göre bu hadîsi ilk râvîsi olan Ali b. Ali er-Râfiî, Hasan el-Basrî̀'den mürsel olarak da rivâyet ettiği için Ahmed b. Hanbel bunun sahîh bir hadîs olmadığını söylemiştir. Ancak zayıf da olsa merfû olarak da rivâyet edilmiştir. (Zeynüddîn Abdurrahmân b. Ahmed el-Bağdâdî İ̉n Receb el-Hanbelî, Fethu'l-Bârî şerhu Sahîhi'l-Buhârî, thk. Mahmud b. Şaban b. Abdilmaksûd vdğr. (Medine: Mektebetü'l-ğurabâi'l-eseriyye, 1417/1996), 6: 429.) 
A. GÖZÜN / Determination and Evaluation of Praying Places and Forms in Prayer with Hadîths | 233

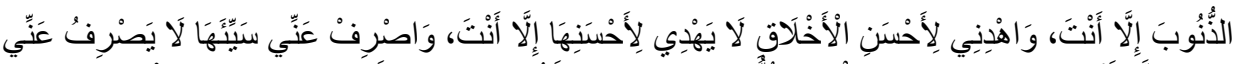

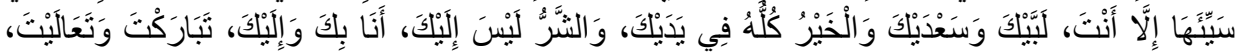

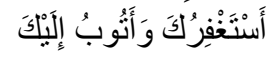

"Yüzümü (zatımı) hanîf olarak gökleri ve yeryüzünü yoktan var edene yönlendirdim ve ben müşriklerden değilim. Şüphesiz benim namazım, ibadetim, yaşamım ve ölümüm âlemlerin rabbi olan Allah (c.c.) içindir. Onun hiçbir ortă̆ı yoktur. Ben bununla emrolundum ve ben teslim olanlardanım. Allah'ım! Sadece sen meliksin. Senden başka hiçbir ilah yoktur. Sen rabbimsin. Ben de senin kulunum. Kendime zulmettim ve günahım itiraf ettim. Benim bütün günahlarımı bağışla! Zira günahları ancak sen bağışlarsın. Beni en güzel ahlâka ulaştır! Zira ahlâkın en güzeline ancak sen ulaştırırsın. Ahlâkın kötüsünü benden uzak kıl! Zira ahlâkın kötüsünü benden ancak sen uzak kılarsın. Emrine âmâdeyim. Hayrun hepsi senin ellerindedir. Şer ise sana değildir (nispet edilmez. Ben seninleyim (yardımınla muvaffak olurum) ve sanayım (sana iltica ederim). Sen mübarek ve yüce oldun. Senden mağfiret ister ve sana tevbe ederim." 22

Şâfî̂ler farz veya nafile ayrımı yapmaksızın daha çok bu sîgayı tercih etmişlerdir. ${ }^{23}$ Hatta İmam Şâfiî (ö. 204/820) mezkûr rivâyeti naklettikten sonra şunu ifade etmiştir: "Artırma veya eksiltme yapılmaksızın bu duanın hepsinin yapılmasını seviyor, emrediyor ve söylüyorum. Sadece وأنا أول المسلمين gerine وأنا من المسلمين denilmelidir."24 Ancak İbn Kayyim el-Cevziyye (ö. 751/1350) "Mahfûz olan, Hz. Peygamber'in (s.a.v.) bu duayı gece namazlarında yapmış olduğudur." demektedir. ${ }^{25}$ Yukarıda ifade edildiği gibi Hanefîler de bu görüştedir.

3. Sîga: Ebû Hüreyre'den rivâyet edildiğine göre, Hz. Peygamber (s.a.v.) namaza başladığında iftitâh tekbiriyle kıraat arasında bir müddet sükût ederdi. Ebû Hüreyre ona "Anam babam sana feda olsun Yâ Resûlallah! Tekbir ile kıraat arasında susunca ne söylüyorsun?" diye sorduğunda ise şu duayı yaptığını ona bildirmiştir:

22 Müslim, "Salâtü'l-müsâfirîn ve Kasruhâ", 201; Ebû Dâvûd, "Salât", 118; Tirmizî, "Deavât", 32; Abdurrezzâk, Musannef, 2: 79.

23 Ebû Yahya Zekeriyya b. Muhammed b. Ahmed b. Zekeriyya el-Ensârî es-Süneykî, Fethu'l-vehhâb bi şerhi Menheci't-tullâb (Beyrut: Dâru'l-fikr, 1414/1994), 1: 48; Ebü'lAbbâs Şihâbüddîn Ahmed b. Lü'lü' b. Abdillah ibnü'n-Nakîb er-Rûmî, Umdetü's-sâlik ve uddetü'n-nâsik (Katar: eş-Şuûnü'd-dîniyye, 1982), 1: 47.

24 Ebû Abdillah Muhammed b. İdris el-Kuraşî eş-Şâfiî, el-Ümm (Beyrut: Dâru'l-ma'rife, 1410/1990), 1: 128.

25 İbn Kayyim el-Cevziyye, Zâdu'l-meâd, 1: 195. 
234 | A. GÖZÜN / Namazdaki Dua Yerleriyle Şekillerinin Hadîslerle Tespiti ve Değerlendirilmesi

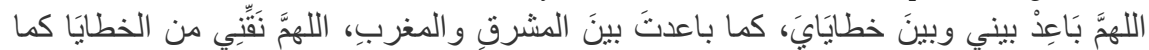

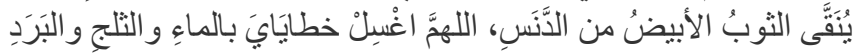

"Allah'ım! Benimle hatalarımın arasına doğu ile batının arasına koyduğun uzaklık gibi uzaklık koy! Allah'ım! Beyaz elbisenin kirden arındırılması gibi beni de hatalardan arındır! Allah'ım! Hatalarımı su, kar ve doluyla yıka!"26 Nevevî (ö. 676/1277) konuyla ilgili farklı hadîsleri naklederken ilk önce mezkûr rivâyeti zikretmiştir. ${ }^{27}$ Bu rivâyette mutlak bir ifade vardır. Dolayısıyla zahirinden mezkûr duanın farz ve nafile olmak üzere bütün namazlarda yapılabileceği anlaşılmaktadır.

Ayrıca Buhârî (ö. 256/870) ve Müslim'in (ö. 261/875) ittifak ettiği bir rivâyet olmasına rağmen fakîhlerin güzel görmekle yetinip mezkûr duayı tercih etmemiş olmaları dikkate şayandır. Nitekim Şevkânî (ö. 1250/1834)) konuyla ilgili bazı rivâyetleri zikrettikten sonra şunu ifade etmiştir: “Şüphesiz Hz. Peygamber' den (s.a.v.) daha sahih olarak rivâyet edilen sîgalar tercihi evlâ olanlardır. İstiftâh duasında rivâyet edilen en sahîh sîga ise Ebû Hureyre rivâyetindeki duadır. Daha sonra ise Hz. Ali'nin rivâyet ettiği dua sîgasıdır." 28

Hz. Peygamber'den (s.a.v.) nakledilen bazı istiftâh duaları ise gece (teheccüd) namazına mahsustur. Bu durum ilgili rivâyet metinlerinde açıkça ifade edilmektedir. Bunlardan meşhur olan üç tanesi örnek olarak aşağıda zikredilecektir.

4. Sîga: Abdurrahman b. Avf'ın oğlu Ebû Seleme (ö. 94/712-13) şöyle anlatmaktadır: Müminlerin annesi $\mathrm{Hz}$. Aişe'ye Resûlullah'ın (s.a.v.) gece kalkınca namazına neyle başladığını sorduğumda şu duayla başladığını söylemiştir:

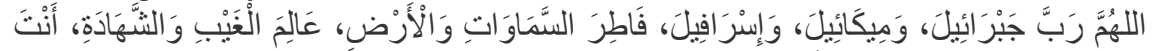

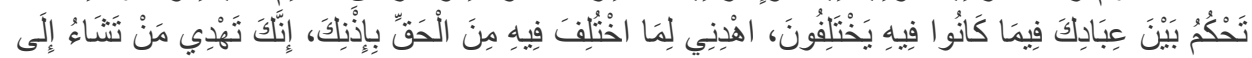

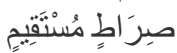

"Cebrâil, Mîkâil ve İsrâfil'in rabbi, gökleri ve yeryüzünü yoktan var eden, gaybı ve şehâdeti bilen Allah'ım! Sen ihtilaf ediyor oldukları konularda

26 Buhârî, "Ezân", 89; Müslim, "el-Mesâcid ve mevâziu's-salât", 147; Ebû Dâvûd, "Salât", 120; İbn Mâce, “İkâmetü's-salât", 1; İbn Ebî Şeybe, Musannef, 6: 26.

27 Nevevî, el-Mecmî̀', 3: 319.

28 Muhammed b. Ali b. Muhammed b. Abdillah el-Yemenî eş-Şevkânî, Neylü'l-evtâr, thk. Isâmüddîn es-Sabâbatî (Mısır: Dâru'l-hadîs, 1413/1993), 2: 228. 
kullarını arasında hüküm vereceksin. Beni izninle kendisinde ihtilaf edilen hakka ulaştır! Zira şüphesiz sen dilediŏini dosdoğru yola ulaştırırsın."29

5. Sîga: İbn Abbâs'tan rivâyet edildiğine göre, Resûlullah (s.a.v.) gece namaza kalktığında (durduğunda) şu duayı yapardı:

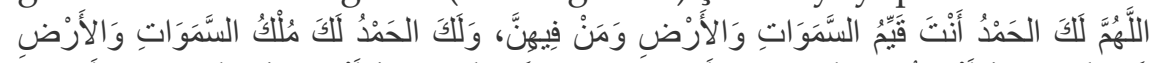

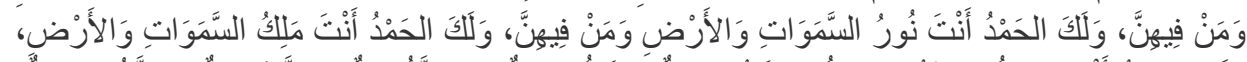

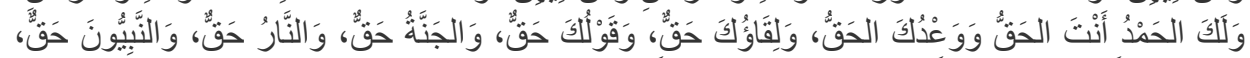

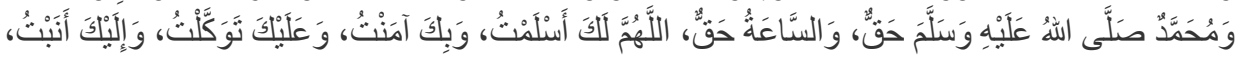

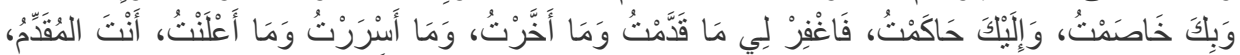

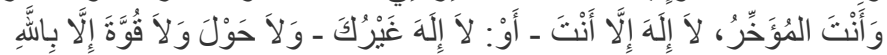

"Allah'ım! Hamd sana mahsustur. Sen gökleri, yeryüzünü ve içindekileri idare edensin. Hamd sana mahsustur. Göklerin, yerin ve içindekilerin mülkü sana aittir. Hamd sana mahsustur. Sen göklerin, yerin ve içindekilerin nurusun. Hamd sana mahsustur. Sen göklerin ve yerin sahibisin. Hamd sana mahsustur. Sen haksın. Vaad ettiğin şey, seninle karşılaşma, sözün, cennet, ateş, peygamberler, Muhammed (s.a.v.), ve kıyamet de haktır. Allah'ım! Sana teslim oldum. Sana inandım. Sana tevekkül ettim. Sana yöneldim. Senin yardımınla hasımlaştım. Senin hükmüne razı oldum. Önce ve sonra, gizli ve açık işlediklerimi bă̆ışla! Sen takdîm ve tehîr edensin. Senden başka ilah yoktur ve ancak senin yardımınla günahlardan uzak kalınıp itaata güç yetirilir."30

6. Sîga: Hz. Âişe kendisine Resûlullah'ın (s.a.v.) gece namazına nasıl başladığını soran kişiye şöyle cevap vermiştir: "Daha önce kimsenin sormadığı şeyi bana sordun. Resûlullah (s.a.v.) kıyama durduğunda on defa tekbir, on defa hamd, on defa tesbih, on kere tehlîl

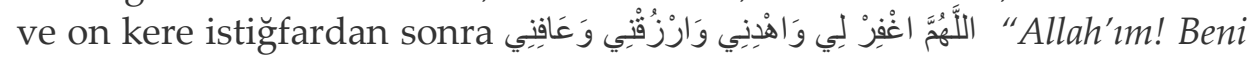
bağışla, bana hidayet et, beni rızıklandır ve bana afiyet ver!" diye dua ederdi ve kıyamet günü yer darlığından Allah'a (c.c.) sı̆̆ınırdı." 31

29 Müslim, "Salâtü'l-müsâfirîn ve Kasruhâ", 200; Ebû Dâvûd, "Salât", 118; Tirmizî, "Deavât", 32; Nesâî, "Kiyamu'l-leyl ve Tatavvu'u'n-nehâr", 12; İbn Mâce, "İkâmetü's-salât", 180.

30 Buhârî, "Teheccüd", 1; Müslüm, "Salâtü'l-müsâfirîn ve Kasruhâ", 199; Ebû Dâvûd, "Salât", 118; Tirmizî, "Deavât", 29; İbn Mâce, "İkâmetü's-salât", 180; Muvattâ, “Kur'ân”, 38; Ebû Bekir Abdullah b. Zübeyr b. İsa el-Kuraşî el-Esedî el-Humeydî, Müsned, thk. Hasan Selîm Esed ed-Dârânî (Dımaşk: Dârussikâ, 1996), 1: 440.

31 Ebû Dâvûd, "Salât", 118; Nesâî, "İstiâze", 63; İbn Mâce, "İkâmetü's-salât", 180; İbn Ebî Şeybe, Musannef, 6: 43. Tespit edilen istiftâh duasının sîgalarının dişında bazı rivâyetlerde iftitâh tekbiri için de farklı sîgalar vârid olmuştur. Örnek olarak İbn Ömer şöyle anlatmaktadır: Bir ara Resûlullah'la (s.a.v.) beraber namaz kılıyorduk.

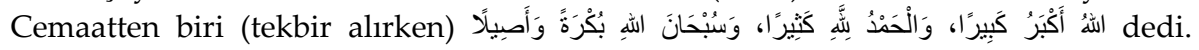


236 | A. GÖZÜN / Namazdaki Dua Yerleriyle Şekillerinin Hadîslerle Tespiti ve Değerlendirilmesi

Görüldüğü gibi son üç rivâyette Hz. Peygamber'in (s.a.v.) bu duaları gece namazlarında yaptığı açıkça ifade edilmektedir. Dolayısıyla sünnete uygun olan bu duaları gece namazlarına tahsis etmektir. İlk üç rivâyette zikredilen istiftâh duaları ise gece namazıyla takyîd edilmediğinden daha çok mutlak olduğu anlaşılmaktadır.

Hattâbî (ö. 388/998) bu husustaki farklı görüşleri aktardıktan sonra şöyle bir değerlendirme yapmaktadır: "Bu mubâh olan ihtilaftandır. Dolayısıyla kişi bu sîgalardan hangisiyle istiftâh ederse caiz olur. Şayet biri Mâlik'in görüşünü alarak bunlardan hiçbirini okumazsa kerahetle namazı geçerli olur."32 İbn Kayyim el-Cevziyye de istiftâh duasıyla ilgili mezkûr rivâyetleri aktardıktan sonra bunların içerisinde birinci sîganın daha faziletli olduğunu birtakım delillerle ispat etmeye çalışmaktadır. Diğer sîgaların ise daha çok nafile olan gece namazlarında yapılabileceğini dile getirmektedir. ${ }^{33}$

\section{Fâtiha'dan Sonra Yapilan Dua}

Bazı hadîslerden namaz içerisinde ikinci dua yerinin, kıyamın ikinci yarısı olan Fâtiha sonrası olduğu anlaşılmaktadır. Nitekim birtakım rivâyetlerde Resûlullah'ın (s.a.v.) (gece) nafile namazlarda zamm-1 sûre okurken aynı zamanda dua ettiği vârid olmuştur. $\mathrm{O}$ rivâyetlerden birinde Avf b. Mâlik şöyle anlatmaktadır: "Resûlullah'la (s.a.v.) beraber (gece) namaza durdum. Önce misvak kullanıp abdest aldı. Sonra kıyama durup namaza başladı. (Fâtiha'dan sonra birinci rekâta) Bakara süresiyle başladı. Her rahmet âyetine geldiğinde durup (Allah'tan (c.c.) rahmetini) istiyor, her azap âyetine uğradiğında da durup (azabından Allah'a (c.c.)) sığınıyordu. Sonra rükûya gitti.

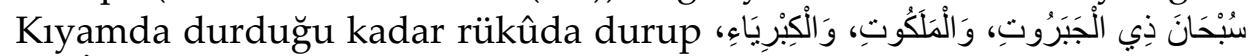
وَالْغَظََةِة diyerek Allah'1 (c.c.) tesbih etti. Sonra da secdeye kapandı ve rükûda kaldığı kadar da secdede kalarak aynı tesbihi yaptı. Daha sonra

Resûlullah (s.a.v.) (namazdan sonra) 'O sözleri söyleyen kim idi?' diye sordu. Adam cevaben ‘Ben yâ Resûlellah!' deyince Hz. Peygamber (s.a.v.) şöyle buyurdu: 'O sözlere şaşırdım. Zira onlar için gök kapıları açıldı.' Resûlullah'ın (s.a.v.) bu sözünü işittiğimden beri ben o cümleleri hiç bırakmadım." (Müslim, "el-Mesâcid ve mevâziu's-salât", 150; Tirmizî, "Deavât", 126; Nesâî, "İftitâh", 8; Ahmed b. Hanbel, Müsned, 2: 14). Ancak çalışmada sadece tekbîrden sonra yapılan dualar ele alındığı için mezkûr iftitâh sîgalarına değinilmeyecektir.

32 Ebû Süleyman Hamd b. Muhammed b. İbrahim el-Büstî el-Hattâbî, Meâlimü's-sünen (b.y.: el-Matbaatü'1-ilmiyye, 1351/1932), 1: 197.

33 İbn Kayyim el-Cevziyye, Zâdu'l-meâd, 1: 196. 
(ikinci rekâtta) Âl-i İmrân sûresini ve (diğer rekâtlarda) başka sûreleri okuyarak (birinci rekâtta yaptığının) aynısını yaptı."34

Benzer bir rivâyette Hz. Huzeyfe bir seferinde Resûlullah'la (s.a.v.) beraber kıldığ1 (nafile) namazı şöyle tarif etmektedir: “Rükûda ربحان ربي العظيم; secdede ise سبحان ربي الأعلى diyordu ve her rahmet âyetine geldiğinde durup (Allah'tan (c.c.) rahmetini) istiyordu, her azap âyetine uğradığında da durup (azabından Allah'a (c.c.)) sığınıyordu." 35

Hanbelîlerden İbn Kudâme (ö. 682/1283) mezkûr rivâyetleri delil göstererek şunu söylemektedir: Nafile namaz kılan kimsenin rahmet ayetine geldiğinde (Allah'tan (c.c.)) rahmet istemesi, azap ayetine uğradığında ise azaptan (Allah'a (c.c.)) sığınması müstehab olur." ${ }^{36}$ Şâfiîlerden Nevevî ise müstehab hükmünü açıkça ifade etmese de mezkûr rivâyetleri zikretmekle bunun müstehab olduğuna işaret etmiştir. ${ }^{37}$

Sonuç olarak bu rivâyetlerden Hz. Peygamber'in (s.a.v.) gece namazında/nafile namazlarda Fâtiha'dan sonra zamm-1 sûre okurken zikredilen şekilde dua ettiği açıkça anlaşılmaktadır. Dolayısıyla nafile namaz kılan kimsenin zamm-1 sûre okurken Hz. Peygamber'in (s.a.v.) yaptığına benzer bir şekilde dua etmesi caiz ve müstehab olsa gerektir.

Farz namazlarda ise bunun benzerini yaptığına dair herhangi bir rivâyete tarafımızca rastlanılmamıştır. Ancak tâbiûnden bazı âlimlerin cemaatle kılınan farz namazlarda zamm-1 sûreye başlamadan Fâtiha'dan sonra dua ettiklerine/dua etmeyi tavsiye ettiklerine dair bazı rivâyetler vârid olmuştur. Bazıları şunlardır:

34 Ebû Dâvûd, "Salât", 146; Nesâ̂̂, "Tatbîk", 12, 73; Ahmed b. Hanbel, Müsned, 6: 24; Ebü'l-Kâsım Süleyman b. Ahmed b. Eyyüb el-Lahmî eş-Şâmî et-Taberânî, elMu'cemu'l-kebîr, thk. Hamdî b. Abdilmecîd es-Selefî (Kahire: Mektebetü İbn Teymiyye, 1415/1994), 18: 61. Şevkânî hadîsin isnâdındaki ricâlin sika olduğunu söylemiştir. (Şevkânî, Neylü'l-evtâr, 2: 381.) Nesâî şârihlerinden Esyûbî de hadîsin râvîlerini tek tek inceleyip herbirinin sika yahut sadûk olduğunu dile getirmiştir. (Muahmmed b. Ali b. Âdem b. Musa el-Vellevî el-Esyûbî, Zahîratü'l-ukbâ fì şerhi'lMüctebâ (b.y.: Dâru'l-mirâc, 1416-1424/1996-2003), 13: 159.) Elbânî de rivâyetin isnâdının sahih olduğunu ifade etmiştir. (Ebû Abdirrahmân Muhammed Nâsıruddîn b. el-Hâcc Nuh b. Necâtî b. Âdem el-Elbânî, Sahîhu Ebî Dâvûd (Kuveyt: Müessesetü ğirâs, 1423/2002), 4: 27.)

35 Ebû Dâvûd, "Salât", 145; Tirmizî̀, "Salât", 79; Ahmed b. Hanbel, Müsned, 5: 394.

36 İbn Kudâme, el-Muğnî, 1: 394.

37 Nevevî, el-Mecmû',3: 413. 
238 | A. GÖZÜN / Namazdaki Dua Yerleriyle Şekillerinin Hadîslerle Tespiti ve Değerlendirilmesi

1. Yunus'tan (ö. 139/756) Mücâhid'in (ö. 103/721) şöyle dediği

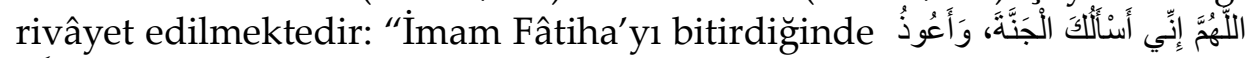

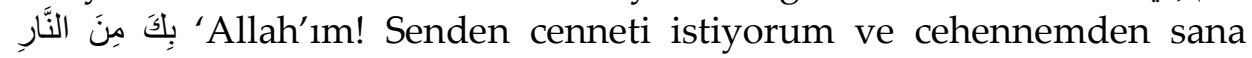
siğınıyorum.' de!"38

2. Ebû Ya'lâ'dan (ö. 307/919) rivâyet edildiğine göre Rebî' b. Huseym (ö. 65/685?), imam Fatiha'y1 bitirdiğinde اللَُّعَّ اغْفِرْ لِي، أَمِينَ 'Allah'ım! Beni bağışla! Amin.' derdi." 39

3. İbn Ebî Şeybe'nin (ö. 235/849 rivâyet ettiğine göre yine Rabî' b. Haysem şöyle demiştir: “İmam Fatiha'yı bitirdiğinde Allah'tan (c.c.) dilediğin şeyde yardım iste!" 40

4. Ebû Hamza (ö. 148/765), İbrahim en-Nehaî'nin şöyle dediğini rivâyet etmiştir: “İmam Fatiha'y1 bitirdiğinde اللَّهَُّ اغْفْرْ لِي، آمِينَ demek müstehab olur." 41

Bu rivâyetlerden zamm-1 sûreye başlamadan Fâtiha'dan sonra dua etmenin bazı âlimlere göre müstehab olduğu anlaşılmaktadır. Ancak fakîhler tespit edebildiğimiz kadarıla bu konuya pek değinmemişlerdir. Bunun sebebinin Hz. Peygamber'den (s.a.v.) buna dair bir rivâyetin vârid olmaması olduğu söylenebilir. Vitir namazında zamm-1 sûreden sonra okunan kunût duası ise daha önce de ifade edildiği gibi çalışmanın kapsamına dahil edilmemiştir.

\section{Rükûda Yapılan Dua}

Tespit edildiği kadarıyla namazdaki dua yerlerinden üçüncüsü rükû halidir. Nitekim bazı rivâyetlerde Hz. Peygamber'in (s.a.v.) namaz kılarken rükûda bilinen tesbihin dışında dua ettiği vârid olmuştur. $\mathrm{O}$ rivâyetlerden bazıları aşağıda zikredilecektir.

Hz. Aişe'den rivâyet edildiğine göre Resûlullah (s.a.v.) rükûsunda ve secdesinde Kur'ân'ı (Nasr sûresini) yorumlayarak şu duayı çokça

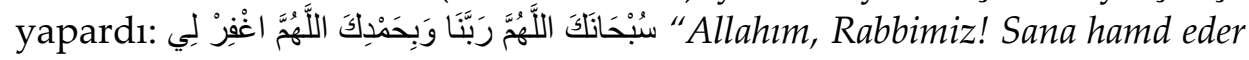
ve seni tesbih ederim. Allah'ım! Beni bağışla!"42 Bu rivâyette mutlak bir ifade olduğundan, farz yahut nafile ayrımı olmaksızın $\mathrm{Hz}$. Peygamber'in (s.a.v.) rükûda mezkûr duayı yaptığı anlaşılmaktadır.

38 İbn Ebî Şeybe, Musannef, 2: 188.

39 İbn Ebî Şeybe, Musannef, 2: 187.

40 İbn Ebî Şeybe, Musannef, 2: 187.

41 İbn Ebî Şeybe, Musannef, 2: 187.

42 Buhârî, "Ezân", 123, 139; Müslim, "Salât", 217; Ebû Dâvûd, "Salât", 147; Nesâî, "Tatbîk", 65; Abdurrezzâk, Musannef, 2: 155. 
Muhammed b. Mesleme'den rivâyet edildiğine göre ise Resûlullah (s.a.v.) nafile namaz kıldığında rükû edince şu duayı yapardı:

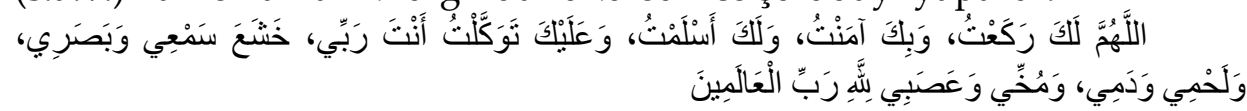

"Allah'ım! Sana rükû ettim. Sana inandım. Sana teslim oldum. Sana tevekkül ettim. Sen rabbimsin. Kulağım, gözüm, etim, kanım, beynim ve sinirlerim âlemlerin rabbi olan Allah'a (c.c.) boyun eğmiştir." 43 Geride Hz. Ali'den nakledilen rivâyette bu dua daha kısa olarak şu şekilde

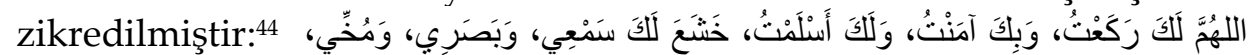
Ayrica bu rivâyette nafile kaydı geçmemektedir.

Buna binâen Şâfiî,, "Rükûda Söylenecekler" başlı̆̆1 altında Hz. Ali'den nakledilen rivâyeti zikrederek mezkûr duanın müstahab olduğuna işaret etmiştir. ${ }^{45}$ İbn Rüşd'ün (ö. 520/1126) ifade ettiğine göre Buhârî gibi bazı âlimler de zikredilen rivâyetleri delil göstererek rükûda dua etmenin caiz olduğunu söylemişlerdir. Mâlik gibi bazıları ise başka rivâyetlerden ${ }^{46}$ yola çıkarak bunun mekrûh olduğunu savunmuşlardır. ${ }^{47}$ Karâfî (ö. 684/1285) de birinci rivâyete istinaden Süfyân es-Sevrî́nin (ö. 161/778) görüşüne itiraz sadedinde rükû ve secdenin tesbihle ve belli bir sayıyla sınırlanamayacağını söylemiştir. ${ }^{48}$

Yine Mâlikîlerden Lahmî, Mâlik'in müstehab olarak görmediğini naklettikten sonra bu rivâyeti delil göstererek rükûda dua etmenin menedilen bir durum olmadığını ifade etmiştir. ${ }^{49}$ Ayrıca Şâfiîlerden Nevevî "Rükû ve Secdenin Zikirleri Hakkında Vârid Olan Hadîsler"

43 Nesâî, "Tatbîk", 14. İbnü’l-Mülakkın rivâyetin başka rivâyetlerle desteklendiği için sahih olduğuna işaret etmiştir. (Ebû Hafs Siracüddîn Ömer b. Ali b. Ahmed el-Misrî İbnü'l-Mülakkın eş-Şâfiî, el-Bedru'l-münîr fî tahrîci'l-ehâdîsi ve'l-âsâri'l-vâkı'ati fi'ş-şerhilkebîr, thk. Mustafa Ebü'l-ğayt vdğr. (Riyad: Dâru'l-hicret, 1425/2004), 3: 615).

44 Müslim, "Salâtü'l-müsâfirîn ve Kasruhâ", 201; Ebû Dâvûd, "Salât", 118; Tirmizî, "Deavât", 32; Abdurrezzâk, Musannef, 2: 79.

45 Şâfiî, el-Ümm, 1: 128.

46 Rükûda Allah'ın (c.c.) tâzim edilmesinin emredildiğini ifade eden ilgili rivâyet, ileride "Secdede Yapılan Dua" başlı̆̆ı altında zikredilecektir.

47 Ebü'l-Velîd Muhammed b. Ahmed b. Muhammed b. Ahmed İbn Rüşd el-Kurtubî, Bidâyetü'l-müctehid ve nihâyetü'l-muktesid (Kahire: Dâru'l-hadîs, 1425/2004), 1: 137.

48 Ebü'l-Abbâs Şihâbüddîn Ahmed b. İdris b. Abdirrahmân el-Mâlikî el-Karâfî, ezZehîra, thk. Muhammed Hacı vd̆̆r. (Beyrut: Dâru'l-ğarbi'l-islâmî, 1994), 2: 225.

49 Lahmî, et-Tebsıra, 1: 418. 
240 | A. GÖZÜN / Namazdaki Dua Yerleriyle Şekillerinin Hadîslerle Tespiti ve Değerlendirilmesi başlığı altında birinci rivâyeti zikrederek bunun müstehab olduğuna işaret etmiştir. ${ }^{50}$

Genel olarak Hanefîlere ve Hanbelîlere göre ise rükûda tesbihle yetinilmesi gerekir. Dua yapılması uygun değildir. Hanefîlerden Cessâs (ö. 370/981), Hz. Âli'den bu konuda vârid olan rivâyetlerin ve benzerlerinin tesbih rivâyetleriyle mensuh olduğunu dile getirmektedir. ${ }^{51}$ Ancak Aynî bunun farz namazlarda geçerli olduğunu, nafile namazlarda ise genişlik olduğundan mezkûr duaların nafilelerde yapilabileceğini ifade etmektedir. ${ }^{52}$

Sonuç olarak bazı âlimlere göre tüm namazların, bazılarına göre de sadece nafile namazların rükûsunda me’sûr duaların yapılması müstehab yahut caiz olur. Ancak İbn Battâl'in (ö. 449/1057) kaydettiğine göre diğer bazı âlimler ilgili rivâyetlerden yola çıkarak kişinin sadece rivâyetlerde geçen şekilde değil istediği herhangi bir şekilde dua edilebileceği görüşüne sahip olmuşlardır.53 Ayrıca mezkûr duaların dışında Hz. Peygamber' in (s.a.v.) farklı tesbih sîgalarıyla rükûda rabbini tesbih ettiği birtakım rivâyetlerde vârid olsa da bunlar dua içermeyip sadece tesbih oldukları için burada ele alınmamışlardır. ${ }^{54}$

\section{Rükûdan Kalkıldığında (İtidâl) Yapılan Dua}

Yapılan araştırmalardan namaz içerisinde dördüncü dua yerinin (rükûdan kalkılınca) itidâl hali olduğu tespit edilmiştir. Nitekim bazı rivâyetlerde Hz. Peygamber'in (s.a.v.) başını rükûdan kaldırdığında da birtakım dualar yaptığı vârid olmuştur. Bu tür rivâyetlerden bazıları aşağıda ele alınacaktır.

Abdullah b. Ebî Evfâ'dan rivâyet edildiğine göre Resûlullah (s.a.v.) başını rükûdan kaldırdı̆̆ında şu duayı yapardı:

50 Nevevî, el-Mecmû',3: 413.

51 Ebü'l-Hasan Alâuddîn Ali b. Süleyman ed-Dımaşkî el-Merdâvî, el-İnsâf fì ma'rifeti'rrâcihi mine'l-hilâf (b.y.: Dâru ihyâi't-türâsi'l-arabî, ts.), 2: 60; Ebû Bekir Ahmed b. Ali Cessâs er-Râzî, Şerhu Muhtasari't-Tahâvî, thk. İsmetüllah İnâyetüllah Muhammed vdğr. (Dâru's-sirâc, 1431/2010), 1: 582.

52 Ebû Muhammed Bedruddîn Mahmud b. Ahmed b. Musa el-Aynî, Umdetü'l-kârî şerhu Sahîhi'l-Buhârî (Beyrut: Dâru ihyâi't-türâsi'l-arabî, ts.), 6: 68.

53 Ebü'l-Hasan Ali b. Halef b. Abdilmelik İbn Battâl, Şerhu Sahîhi'l-Buhârî, thk. Ebû Temîm Yâsir b. İbrahim (Riyad: Mektebetü'r-rüşd, 1423/2003), 2: 412.

54 Örnek olarak Hz. Âişe'den rivâyet edildiğine göre Resûlullah (s.a.v.) rükûsunda ve

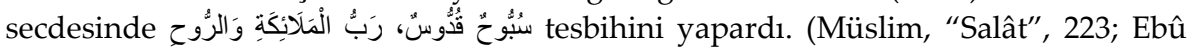
Dâvûd, "Salât", 146; Nesâî, "Tatbîk", 75). 
A. GÖZÜN / Determination and Evaluation of Praying Places and Forms in Prayer with Hadîths | 241

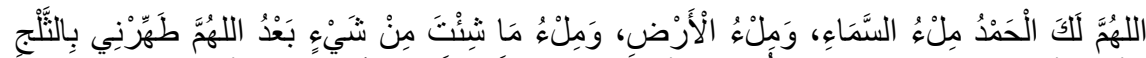

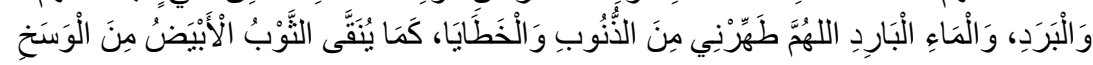

"Allah'ım! Gökyüzü, yeryüzü ve bunların dişında dilediğin şeyler dolusunca hamd sana mahsustur. Allah'ım! Beni karla, doluyla ve soğuk suyla yıka! Allah'ım! Beyaz elbisenin kirden arındırıldı̆̆ı gibi beni günahlardan ve hatalardan temizle!" $55 \mathrm{~Hz}$. Ali'den gelen rivâyette bu dua, hamd kisminin bulunduğu şu sîgadan ibarettir: ${ }^{56}$

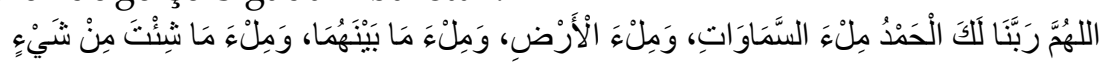

Ebû Saîd el-Hudrî'den gelen rivâyete göre ise Resûlullah (s.a.v.) başını rükûdan kaldırdığında şunu söylerdi:

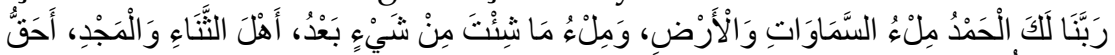

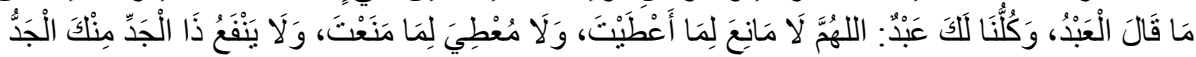

“Ey rabbimiz! Ey övgü ve şeref sahibi! Gökler, yeryüzü ve bunlarn dışında dilediğin şeyler dolusunca hamd sana mahsustur. Hepimiz senin kulunuz. Kulun söylediği en hak söz şudur: 'Allah'ım! Senin verdiğini menedecek hiç kimse yoktur. Senin menettiğini de verecek hiç kimse yoktur ve sana karşı zenginlik sahibine zenginliği hiçbir fayda vermez.' "57

İbn Hacer birinci rivâyetteki duayı delil göstererek namazdaki dua yerlerinden ikincisinin itidâl (rükûdan kalkış) olduğunu söylemiştir. ${ }^{58}$ Hanbelîlerden Lahmî de bu rivâyeti zikrederek mezkûr duanın sünnet olduğuna işaret etmiştir. ${ }^{59}$ Merdâvî (ö. 885/1480) ise bu duanın müstehab olduğunu açıkça ifade etmiştir. ${ }^{60}$ İbn Teymiyye (ö. 728/1328) ise namazdaki dua yerleriyle alakalı genel olarak şunu ifade etmiştir: "Hz. Peygamber'in (s.a.v.) farz olsun nafile olsun rükûda, rükûdan başını kaldırdığında ve secdede dua ettiği rivâyetlerle sabit olmuştur. Namazın sonunda yaptığ 1 dualar ise tevatürle sabittir." 61 Dolayısıyla ona göre bu

55 Müslim, “Salât”, 204.

56 Müslim, "Salâtü'l-müsâfirîn ve Kasruhâ", 201; Ebû Dâvûd, "Salât", 118; Tirmizî, "Deavât", 32; Abdurrezzâk, Musannef, 2: 79.

57 Müslim, "Salât", 205.

58 İbn Hacer, Fethu'l-Bârî, 11: 132.

59 Lahmî, et-Tebsira, 1: 419.

60 Merdâvî, el-İnsâf, 2: 64 .

61 Ebü'l-Abbâs Takıyyüddîn Ahmed b. Abdilhalîm el-Harrânî İbn Teymiyye, Mecmû'u'l-fetâvâ, thk. Abdurrahman b. Muhammed b. Kâsım (Medine: Mücemmeu'lMelik Fehd, 1416/1995), 22: 497. 
242 | A. GÖZÜN / Namazdaki Dua Yerleriyle Şekillerinin Hadîslerle Tespiti ve Değerlendirilmesi dualar sünnettir. Öğrencisi İbn Kayyim el-Cevziyye de birinci rivâyeti zikrederek aynı görüşte olduğuna işaret etmiştir. ${ }^{62}$

Hanefîler ise genel olarak bu tür duaların vârid olduğu rivâyetleri teheccüd namazına yahut nafile namazlara hamletmişlerdir. Dolayısıyla onlara göre farz namazlarda özellikle cemaatle eda edildiğinde ikinci teşehhüd sonrası hâriç rükû, secde ve diğer yerlerde sadece meşhur zikir ve tesbihlerle yetinilmelidir. ${ }^{63}$

Zikredilen duaların dışında sadece hamd veya tesbih ifade eden bazı sîgalar da Hz. Peygamber'den (s.a.v.) vârid olmuş ise de dua içermediği için bu tür rivâyetlere burada temas edilmemiştir. ${ }^{64}$ Ayrıca daha öncede ifade edildiği gibi bazı mezheblere göre sabah namazında rükûdan kalkılınca okunması sünnet olan kunût duasına da çalışmada değinilmeyecektir.

\section{Secdede Yapilan Dua}

Namazdaki dua yerlerinden beşincisi secde halidir. Bu konuyla ilgili Hz. Peygamber'den (s.a.v.) vârid olan rivâyetleri iki kısma ayırmak mümkündür. Birincisi; genel anlamda secdede dua etmeye teşvik eden rivâyetler. İkincisi ise; Hz. Peygamber'in (s.a.v.) bizzat kendisinin secdede yaptığı dualara dair rivâyetler. Aşağıda öncelikle genel olarak secdede dua edilmesini emreden rivâyetler ele alınacaktır.

İbn Abbas, Hz. Peygamber'in (s.a.v.) son hastalı̆̆ındaki bir hadîseyi şöyle anlatmaktadır: "Resûlullah (s.a.v.) evinin perdesini açtı. Insanlar Hz. Ebû Bekir'in arkasında saf tutmuşlardı. Onlara şöyle buyurdu: 'Ey insanlar! Şüphesiz nübüvvetin müjdeleyicilerinden sadece Müslümanın göreceği salih rüya kalmıştır. Dikkat edin! Muhakkak ben rükû

62 Muhammed b. Ebî Bekir b. Eyyüb b. Sa'd İbn Kayyim el-Cevziyye, Şifâu'l-alîl fî mesâili'l-kazâi ve'l-kaderi ve'l-hikmeti ve't-ta'lîl (Beyrut: Dâru'l-ma'rife, 1398/1978), 1: 118.

63 Fahruddîn Osman b. Ali b. Mihcen el-Bâriî ez-Zeylaî, Tebyînü'l-hakâyik şerhu Kenzi'ddekâyik (Bulak: el-Matba'atü'l-kübra'l-emîriyye, 1313), 1: 115; Şemsü'l-eimme Muhammed b. Ahmed b. Ebî Sehl es-Serahsî, el-Mebsût (Beyrut: Dâru'l-ma'rife, 1414/1993), 1: 22.

64 Örnek olarak sahâbeden Rifâ'a b. Râfi' ez-Zirakî şöyle anlatmaktadır: "Bir gün

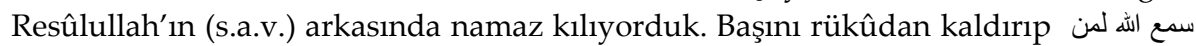

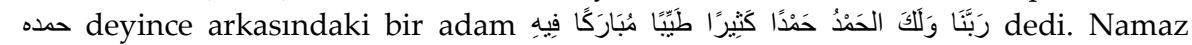
bittikten sonra 'O sözü söyleyem kimdi?' diye sordu. Adam 'Ben idim.' dedi. Bunun üzerine 'Otuz küsur melek gördüm. O sözü (sevabını) ilk yazan olmak için yarışıyorlardı.' buyurdu." (Buhârî, "Ezân", 125; Ebû Dâvûd, "Salât", 118; Nesâî, "Tatbîk", 22; İbn Hibbân, Sahîh, 5: 235.) 

veya secde ederken Kur'an okumaktan nehy olundum. Rükûda Rabb'i tazîm edin. Secdede ise duaya gayret edin. Zira (secdede yapilan dua) kabul olunmaya ziyadesiyle elverişlidir. "' 65

Ebû Hüreyre'den rivâyet edildiğine göre Hz. Peygamber (s.a.v.) şöyle buyurmuştur: "Kulun Allah'a (c.c.) en yakın oldŭ̆u durum secde halidir. O halde duayı çok yapın."66 Her iki rivâyettede Hz. Peygamber'in sarâhaten secdede dua etmeyi emrettiği görülmektedir. Ayrıca başka rivâyetlerden sadece ümmetine emretmekle kalmayıp bizzat kendisinin de farklı sîgalarla secdede dua ettiği anlaşılmaktadır. O rivâyetlerden bazıları şunlardır:

1. Hz. Âişe şöyle anlatmaktadır: Bir gece Resûlullah'ın (s.a.v.) yatakta olmadığını fark ettim. Aramaya başlayınca mescitte secdede olduğu için elim dikili olan ayaklarının tabanına değdi. Secdede şöyle diyordu:

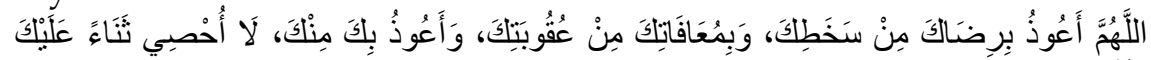

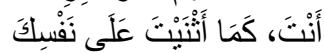

"Allah'ım! Gazabindan rizana, azabindan afiyetine ve senden sana sığınırım. Sana (yaraşır) övgüleri saymakla bitiremem. Sen kendini övdü̆ğ̈n gibisin." 67

2. Hz. Âişe'den nakledilen benzer bir rivâyette ise $\mathrm{Hz}$. اللهمَّ اغفرْ لي ما أسرَرْتُ وما Peygamber'in (s.a.v.) gece namazının secdesinde أعلَنْتُ "Allah'ım! Gizli ve aleni yaptı̆̆ım günahlarımı bağışla!" diye dua ettiği vârid olmuştur. ${ }^{68}$

3. İbn Abbas şöyle anlatıyor: “Bir seferinde teyzem Meymûne'nin yanında geceledim. Resûlullah (s.a.v.) geceleyin uyandı. Namaz kılmaya başladı. Secdeye varınca şu duayı yaptı:

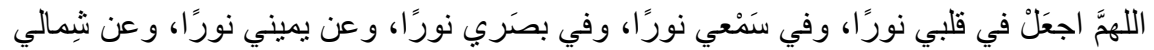

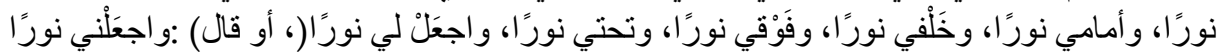

$$
\begin{aligned}
& \text { "Allah'ım! Kalbime, kulağıma, gözüme, să̆ıma, soluma, önüme, arkama, } \\
& \text { üstüme, altıma nur yerleştir ve benim için nur kıl! (beni nur kıl!)"69 }
\end{aligned}
$$

65 Müslim, "Salât", 207; Nesâî, “Tatbîk", 8; Dârimî, "Salât”, 77; Şâfiî, Müsned, Beyrut: Dâru'l-kütübi'l-ilmiyye, 1400, 1: 39.

66 Müslim, “Salât”, 215; Ebû Dâvûd, “Salât”, 147; Beyhakî, es-Sünenü'l-kübrâ, 2: 158.

67 Müslim, "Salât", 222; Ebû Dâvûd, "Salât", 147; Tirmizî, "Deavât", 75; Nesâ̂̂, "Tatbîk", 47; İ̉n Mâce, "Dua", 3; Dârekutnî, Sünen, 1: 261.

68 Nesâî, "Tatbîk", 66; Tayâlisî, Müsned, 3: 32; İbn Ebî Şeybe, Musannef, 6: 30.

69 Buhârî, "Deavât", 10; Müslim, "Salâtü'1-müsâfirîn ve Kasruhâ", 187; Ebû Dâvûd, "Tatavvu", 26; Nesâî, “Tatbîk”, 63. 
244 | A. GÖZÜN / Namazdaki Dua Yerleriyle Şekillerinin Hadîslerle Tespiti ve Değerlendirilmesi

4. Ebû Hüreyre'den rivâyet edildiğine göre Hz. Peygamber (s.a.v.) secdede şu duayı yapard1:

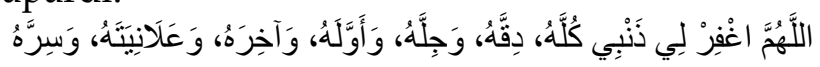

"Allah'ım! Günahlarımın hepsini; azını, çoğunu, başını, sonunu, açığını ve gizlisini bă̆ışla!"70

Zikredilen rivâyetlere bakıldığında Hz. Peygamber'in (s.a.v.) namazların secdelerinde tesbihin dışında birtakım dualar yaptığı açıkça anlaşılmaktadır. Ayrıca me'sûr duaların dişında istenilen duaların çokça yapılmasına ümmetini teşvik etmiş olduğu görünmektedir. Bununla birlikte fakîhler arasında farklı nedenlerle bu konuda da ihtilaf sözkonusudur.

Tahâvî'nin (ö. 321/933) ifade ettiğine göre Hanefîler, Ukbe b. Âmir'den rivâyet edilen; “فن̈yük olan rabbinin adiyla tesbih et!.' (el-Vâkı'a 56/74) âyeti indiğinde Resûlullah (s.a.v.) 'Bunu rükûnuza koyun.' سبح اسم ربك الأعلى 'En yüce olan rabbinin adını tesbih et!.' (el-Âlâ 87/1) âyeti nâzil olduğunda ise 'Bunu da secdenize koyun.' buyurdu." 71 rivâyeti ile Huzeyfe'den nakledilen "Resûlullah (s.a.v.) rükûsunda üç defa سبحان ربي العظيم secdesinde ise üç kere سبحان ربي الأعلى " derdi."72 rivâyetinin vb. tesbihi emreden diğer rivâyetlerin daha önceki hadîsleri ve uygulamaları nesh ettiğini ifade etmişlerdir..$^{73}$ Dolayısıyla geride de ifade edildiği gibi onlara göre rükû ve secdede mezkûr tesbihlerden başka dualar yapılamaz.

70 Müslim, "Salât”, 216; İ̉n Huzeyme, Sahîh, 1: 335; İbn Hibbân, Sahîh, 5: 257.

71 Ebû Dâvûd, "Salât", 146; İbn Mâce, "İkâmetü's-salât", 20; Dârimî, "Salât", 69; İbn Huzeyme, Sahîh, 1: 303; İbn Hibbân, Sahîh, 5: 225; Hâkim, el-Müstedrek, 2: 519. Bu rivâyetle ilgili Elbânînin iki farklı değerlendirmesi sözkonusudur. Bir yerde rivâyetin hasen olduğunu dile getirmiştir. (Ebû Abdillah Veliyyüddîn Muhammed b. Abdillah el-Hatîb el-Ömerî et-Tebrîzî, Mişkâtü̈l-mesâbîh, thk. Muhammed Nâsıruddîn elElbânî (Beyrut: el-Mektebü'l-islâmî, 1985), 1: 277.) Diğer bir yerde ise râvîlerinden İyâs b. Âmir el-Ğâfikî ma'rûf bir râvî olmadığı için bu rivâyetin zayıf olduğunu söylemiştir. (Ebû Abdirrahmân Muhammed Nâsıruddîn b. el-Hâcc Nuh b. Necâtî b. Âdem el-Elbânî, Zaîfu Ebî Dâvûd (Kuveyt: Müessesetü ğirâs, 1423), 1: 337.)

72 İbn Huzeyme, Sahîh, 1: 334; Ebû Bekir Ahmed b. Amr b. Abdilhâlık el-Bezzâr elAtekî, el-Müsned: el-Bahru'z-zehhâr, thk. Mahfûzurrahmân Zeynüllah - Âdil b. Sa'd Sabrî Abdulhâlık eş-Şâfiî (Medine: Mektebetü'l-ulûm ve'l-hikem, 1988-2009), 7: 324;

73 Ebû Cafer Ahmed b. Muhammed b. Selâme el-Ezdî el-Misrî et-Tahâvî, Şerhu meâni'lâsâr, thk. Muhammed Zührî en-Neccâr - Muhammed Seyyid Câdü'l-hakk (Âlemü'lkütüb, 1414/1994), 1: 253. 
Mâlikîler ise rükûda dua yapılmasının mekruh olduğunu söylemekle beraber secdede dua yapmakta bir sakınca olmadığ 1 görüşündedir. ${ }^{74}$ İbn Abdilber de (ö. 463/1071) secdenin dua yeri olduğunu, dolayısıyla namaz kılan kişinin dilerse tesbih dilerse de dua yapabileceğini ifade etmektedir.75 Şâfîiler ise yukarıda zikredilen rivâyetlerden dolayı ister me'sûr olsun ister olmasın mutlak olarak secdede dua etmenin sünnet olduğunu söylemişlerdir. Ancak me'sûr olanlar daha efdaldir. ${ }^{76}$

Hanbelîlerden İbn Kudâme, Kâdî İyâz'ın (ö. 544/1149) “Farz namazın secdesinde tesbihten başka bir şey ziyade edilmesi müstehab olmaz. Çünkü farzda Hz. Peygamber'den (s.a.v.) tesbih emrinden başka bir şey nakledilmemiştir. Nafile namazlarda ise iki rivâyet vardır." dediğini zikrettikten sonra buna itiraz sadedinde şunu ifade etmiştir: "Bu konuda vârid olan sahih haberleri yukarıda zikrettik. Hz. Peygamber'in (s.a.v.) sünneti ittibâ edilmeye daha layıktır. Namazda teşehhüdü emretmesi nasıl duanın meşrûiyyetini nefyetmezse secdede tesbihi emretmesi de başka bir şeyi (duayı) emretmesini nefyetmez. Bir şeyi emretmesi başka bir şeyin nefyi anlamına gelseydi duayı emretmesi de tesbihi nefyederdi. Zira secdede dua ettiği ve bunu emrettiğine dair rivâyetler sahihtir."77 Dolayısıyla fakîhler muhtelif ictihadlarda bulunarak bu hususta farklı görüşlere sahip olmuşlardır. Ancak konuyla ilgili vârid olan hadîslerin çokluğu ve sihhatinden ötürü tüm namazlarda bunun sünnet olduğunu söylemek daha doğru olsa gerektir.

\section{6. İki Secde Arasında Yapılan Dua}

Rivâyetlere göre namazda dua edilebilecek olan yerlerden altıncısı iki secde arasıdır. Çalışmada bu konuyla ilgili de öncelikle vârid olan bazı rivâyetler ele alınacaktır. Daha sonra fakîhlerin bu husutaki

74 Mâlik b. Enes b. Mâlik b. Âmir el-Esbahî el-Medenî, el-Müdevvene (Beyrut: Dâru'1kütübi'l-ilmiyye, 1451/1994), 1: 168.

75 Ebû Ömer Yusuf b. Abdillah b. Muhammed el-Kurtubî İbn Abdilberr, el-Kâfí fî fikhi ehli'l-Medîne, thk. Muhammed Muhammed Ehyed (Riyad: Mektebetü'r-Riyad elhadîse, 1400/1980), 1: 207.

76 Şemsüddîn Muhammed b. Ahmed el-Hatîb eş-Şirbînî, Muğni'l-muhtâc ilâ ma'rifeti meân̂̀ elfâzi'l-Minhâc (Beyrut: Dâru'l-kütübi'l-ilmiyye, 1415/1994), 1: 391; Şemsüddîn Muhammed b. Ebi'l-Abbâs Ahmed Ramlî, Nihâyetü'l-muhtâc ilâ şerhi'l-Minhâc (Beyrut: Dâru'1-fikr, 1404/1984), 1: 549.

77 İbn Kudâme, el-Muğnn̂, 1: 374. 
246 | A. GÖZÜN / Namazdaki Dua Yerleriyle Şekillerinin Hadîslerle Tespiti ve Değerlendirilmesi görüşleri incelenip değerlendirilecektir. İlgili rivâyetlerin bazıları şunlardir:

1. Saîd b. Cübeyr kanaliyla gelen İbn Abbâs rivâyetinin Ebû Dâvûd varyantında Hz. Peygamber'in iki secde arasında şu duayı

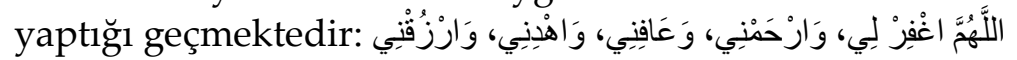

"Allah'ım! Beni bă̆ışla, bana rahmet eyle, bana afiyet ver, beni hidayet et ve beni rizıklandır!."78

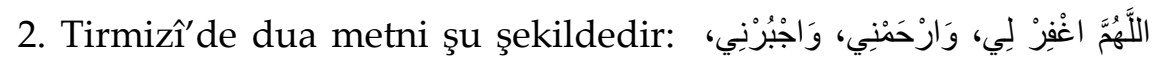
Tirmizî Hz. Ali'den de bu duanın rivâyet edildiğini söylemiş, ayrıca Şâfiî, Ahmed ve İshak'ın hem farz namazlarda hem de nafile namazlarda bu duayı caiz gördüklerini ifade etmiştir. ${ }^{79}$

3. Hz. Huzeyfe'den nakledilen rivâyette Hz. Peygamber'in (s.a.v.) iki secde arasında secde miktarı oturup رب اغفر لي رب اغفر لي dediği zikredilmektedir. ${ }^{80}$

4. İbn Abbas şöyle anlatıyor: “Bir seferinde teyzem Meymûne'nin yanında geceledim. Resûlullah (s.a.v.) geceleyin uyandı. Namaz kılmaya başlad1. Rükûda سُبحانَ ربِّيَ العظيِ secdede ise سُبحانَ ربِّيَ الأعلى dedi. Sonra iki secde arasında şu duayı yaptı:

$$
\text { ربِّ اغفرْ لي، وارحَنْي، واجبُرْني، وارفَعْني، وارزُقْني، واهدِني }
$$

"Rabbim! Beni bağışla, bana rahmet eyle, benim isteğimi yerine getir, beni yükselt, beni rızıklandır ve beni hidayet et." $81 Y$ ukarıda zikredilen rivâyetlerden anlaşıldığı üzere Hz. Peygamber (s.a.v.) iki secde arasında birbirine benzer sîgalarla dua etmiştir. Dolayısıyla namazdaki dua yerlerinden biri de iki secde arasıdır.

Mâlikîler mezkûr rivâyetlerden dolayı bu duanın caiz olup mekruh olmadığını söylemişlerdir. ${ }^{82}$ Şâfiîler sadece caiz olmayıp ayrıca

78 Ebû Dâvûd, "Salât", 140.

79 Tirmizî̀, "Salât", 95.

80 Ebû Dâvûd, "Salât", 146; Nesâî, “Tatbîk”, 86; İbn Mâce, “İkâmetü's-salât”, 23; İbnü'1Ca'd, Müsned, 1: 29. Moğoltay hadîsin sahîh olduğunu ifade etmiştir. (Ebû Abdillah Alâuddîn Moğoltay b. Kılıç b. Abdillah Moğoltay el-Bekcerî el-Misrî, Şerhu Süneni İbn Mâce: el-İ'lâm bi sünnetihi aleyhi's-selâm, thk. Kâmil Uveyda (Suûdiyye: Mektebetü Nizâr Mustafa el-Bâz, 1419/1999), 1: 1510.

81 Ahmed b. Hanbel, Müsned, 1: 371; Taberânî, el-Mu'cemu'l-kebîr, 12: 20; Beyhakî, esSünenü'l-kübrâ, 2: 175.

82 Ebû Abdillah el-Mevvâk Muhammed b. Yusuf b. Ebî Kâsım b. Yusuf el-Abderî elGirnâtî, et-Tâc ve'l-iklîl li Muhatasari Halîl (Beyrut: Dâru'l-kütübi'l-ilmiyye, 1416/1994), 2: 253. 
müstehab olduğunu dile getirmişlerdir. ${ }^{83}$ Hanefîlere gelince Şâfiî olan İmrânî (ö. 558/1163) Ebû Hanîfe'nin burada sünnet olan bir zikir olmadığını söylediğini kaydetmiştir. ${ }^{84}$ Ancak Sadreddîn el-Hanefî (ö. 792/1390) açıç̧a bunun müstehab olduğunu ifade etmese de konuyla ilgili İbn Abbâs'tan vârid olan rivâyeti zikrederek müstehab oluşuna işaret etmektedir. ${ }^{85}$ Hanefîlerden Malatî de (ö. 803/1401) bunun sünnet olduğunu sarâheten ifade etmiştir. ${ }^{86}$

Aynî ise konuyla ilgili daha geniş bir değerlendirme yaparak şunu söylemiştir: "Bize göre iki secde arasında sünnet olan bir zikir/dua yoktur. Çünkü buradaki itidal maksûd değil secdeye tâbidir. Bu hususta vârid olan rivâyetler teheccüde hamledilir. Dâvûd ez-Zâhirî ve Zâhirîlere göre ise bu dua farzdır. Kasten terkedildiğinde namaz batıl olur. ${ }^{87}$

Hanbelîlere göre durum daha farklıdır. Şöyle ki; onlara göre iki secde arasında bir kere رب اغفر لي demek vâcib; secde ve rükûdaki tesbih gibi üç defa söylenmesi ise müstehabtır. Bazı rivâyetlerde gelen diğer uzun dualara gelince bunlar daha çok gece namazlarında müstehab olur. ${ }^{88}$ Ancak Aynî'nin ifade ettiği gibi bu duanın teheccüd namazında geçerli olduğunu söylemek daha isabetli olsa gerektir. Zira Ebû Dâvûd'un Hz. Huzeyfe'den naklettiği hadîsin diğer varyantında açıkça Resûlullah'ın (s.a.v.) gece namazında kıyam süresine yakın bir şekilde uzunca secde ettiği ve iki secde arasında secde süresine yakın miktarda oturup رب اغفر لي رب اغفر لي diye dua ettiği geçmektedir.89 Bununla birlikte mutlak olan birinci rivâyete bakarak tüm namazlarda müstehab olabileceğini söylemek de mümkündür.

83 Ebû Zekeriyya Muhyiddîn Yahya b. Şeref en-Nevevî, Ravzatü't-tâlibîn ve umdetü'lmüftîn, thk. Züheyr eş-Şâvîş (Beyrut: el-Mektebü'l-islâmî, 1412/1991), 1: 260.

84 Ebü'l-Hüseyin Yahya b. Ebi'l-hayr b. Sâlim el-Yemenî el-İmrânî, el-Beyân fî mezhebi'lİmam eş-Şâfiì, thk. Kâsım Muhammed en-Nûrî (Cidde: Dâru'l-minhâc, 1421/2000), 2: 225.

85 Sadruddîn Hanefî, et-Tenbîh alâ müşkilâti'l-Hidâye, 2: 580.

86 Ebü'l-mehâsin Cemâlüddîn Yusuf b. Musa b. Muhammed el-Malatî, el-Mu'tasar mine'l-muhtasar min müşkili'l-âsâr (Beyrut: Âlemü'l-kütüb, ts.), 1: 45.

87 Aynî, Umdetü'l-kârî, 6: 97.

88 İbn Kudâme, el-Muğnî, 1: 377; Şemsüddîn Muhammed b. Abdillah el-Misrî elHanbelî ez-Zerkeşî, Şerhu'z-Zerkeşî alâ Muhatasari'l-Hırakî (b.y.: Dâru'l-Ubeykân, 1413/1993),1: 571; Ebû İshak Burhânüddîn İbrahim b. Muhammed b. Abdillah İbn Müflih, el-Mubdi' fî şerhi'l-Mukni' (Beyrut: Dâru'l-kütübi'l-ilmiyye, 1418/1997), 1: 406.

89 Ebû Dâvûd, "Salât", 146. 
248 | A. GÖZÜN / Namazdaki Dua Yerleriyle Şekillerinin Hadîslerle Tespiti ve Değerlendirilmesi

\section{7. İkinci Teşehhüdden Sonra (Ka'de-i Ahîrede) Yapılan Dua}

Yapılan araştırmalara göre tüm namazlarda dua etmenin bütün fakîhlerin ittifakıyla sünnet olduğu yer ikinci teşehhüd sonrasıdır. Birinci teşehhüdden sonra ise yine ittifakla dua yapılmaz. Ancak Hanefilere ve Hanbelîlere göre insanların sözlerine benzer dualarla dua edilmemesi gerekir. Mâlikî ve Şâfiîlere göre ise me'sûr dualar efdal olmakla beraber böyle bir sınırlama söz konusu değildir. ${ }^{90}$

Secdede dua etmekle ilgili vârid olan rivâyetlerde olduğu gibi bu konuda vârid olan rivâyetleri de iki kısma ayırmak mümkündür. Birincisi; namazın sonunda selam vermeden önce istenilen duanın yapılabileceğine dair genel rivâyetler. İkincisi Hz. Peygamber'in (s.a.v.) burada yaptığı duaların sîgalarını içeren birtakım rivâyetler.

Örnek olarak birinci grup rivâyetlerin birinde Abdullah b. Mes' ûd şöyle anlatmaktadır: "Resûlullah'la (s.a.v.) beraber namaz kıldığımızda

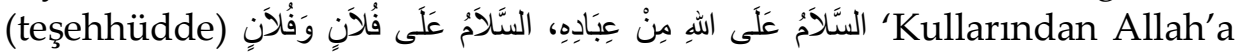
(c.c.) selam olsun. Falana ve filana selam olsun.' derdik. Bunun üzerine Resûlullah (s.a.v.) bizi uyararak; 'Allah'a (c.c.) selam olsun.' demeyin. Zira Allah'ın (c.c.) kendisi selamdır. Bilakis önce şöyle deyin:

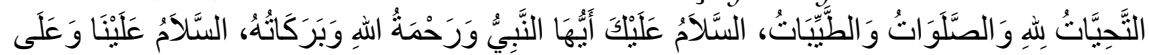

عَبَادِ الهِ الصَّالحِينَ

Bütün tazimler, pak ve temiz olan ibadeler Allah'a (c.c.) aittir. Ey peygamber! Selam, Allah'ın (c.c.) rahmeti ve bereketleri senin üzerine olsun. Bize ve Allah'ın (c.c.) tüm salih kullarına selam olsun.' Böyle dediğinizde

90 Ebû Abdillah Muhammed b. Hasan b. Ferkad eş-Şeybânî, el-Asl:el-Mebsût, thk. Ebü'1vefâ el-Afganî (Karaçi: İdâretü'l-Kur'ân ve'l-ulûmi'l-islâmiyye, ts.), 1: 9; Kâsânî, Bedâyi', 1: 213; Ebû Amr Cemâlüddîn Osman b. Ömer b. Ebî Bekir b. Yunus İbnü'lHâcib el-Kürdî el-Mâlikî, Câmiu'l-ümmehât, thk. Ebû Abdirrahmân el-Ahdar elAhdarî (b.y.: el-Yemâme, 1421/2000), 99; İbn Rüşd, Bidâyetü'l-müctehid, 1: 138; Ebû Abdillah Şemsüddîn Muhammed b. Muhammed b. Abdirrahmân el-Hattâb erRuaynî, Mevâhibü'l-celîl fì şerhi Muhtasari Halîl (b.y.: Dâru'l-fikr, 1412/1992), 1: 543; Ebü'l-Kâsım Abdulkerîm b. Muhammed b. Abdilkerîm el-Kazvînî er-Râfiî, el-Azîz şerhu'l-Vecîz:eş-Şerhu'l-kebîr, thk. Ali Muhammed Ivaz - Âdil Ahmed Abdulmevcûd (Beyrut: Dâru'l-kütübi'l-ilmiyye, 1417/1997), 1: 537; Ebü'l-mehâsin Abdulvâhid b. İsmail er-Rûyânî, Bahru'l-mezheb, thk. Târık Fethî (Beyrut: Dâru'l-kütübi'l-ilmiyye, 2009), 2: 68; Ebu'n-Necâ Şerefüddîn Musa b. Ahmed b. Musa el-Makdisî el-Haccâvî, el-íknâ' fi fikhi'l-İmam Ahmed $b$. Hanbel, thk. Abdullatîf Muhammed Musa es-Sübkî (Beyrut: Dâru'l-ma'rife, ts.), 1: 124; Abdurrahmân b. Abdillah b. Ahmed el-Ba'1î elHalvetî, Keş̧ü'l-muhadderât ve'r-Riyâzu'l-müzhirât li şerhi ahsari'l-muhtesarât, thk. Muhammed b. Nâsır el-Acemî (Beyrut: Dâru'l-beşâiri'l-islâmiyye, 1423/2002), 1: 138. 
göklerde ve yerde bulunan tüm salih kullara selamını gider. Sonra şehadet

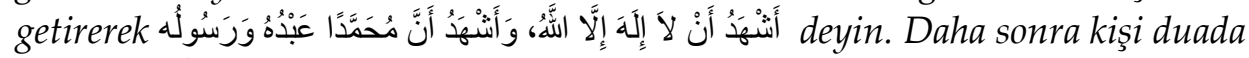
serbesttir. İstediği duayı yapabilir.' buyurdu." 91

Son teşehhüdde selam vermeden önce istenilen duaların yapılabileceğini ifade eden rivâyetlerin dışında $\mathrm{Hz}$. Peygamber'in (s.a.v.) burada yaptığı birtakım dua sîgalarını içeren rivâyetler de vârid olmuştur. Onlardan bazıları şunlardır:

1. Hz. Âişe'den rivâyet edildiğine göre Resûlullah (s.a.v.) namazda (teşehhüdden sonra) şu duayı yapardı:

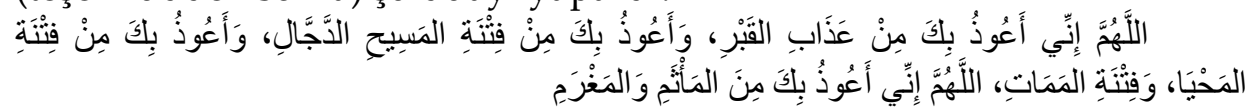

"Allah'ım! Muhakkak kabir azabından, Mesîh Deccâl'in fitnesinden, hayatın ve ölümün fitnesinden sana siğınırım. "Allah'ım! Muhakkak günah işlemekten ve borçlanmaktan sana sığınırım." Adamın biri "Borçlanmaktan ne kadar da çok (Allah'a (c.c.)) sı̆̆ınıyorsun!" deyince "Zira adam borçlandığında konuşur, yalan söyler; söz verir, sözünden cayar." buyurdu. ${ }^{92}$

2. Hz. Ebû Bekir, Resûlullah'a (s.a.v.) "Bana namazda yapacağım bir dua öğret!" deyince şu duayı yapmasını ona emretti:

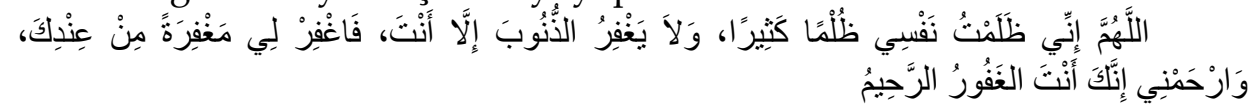

“Allah'ım! Şüphesiz ben kendime çok zulmettim. Günahları ise ancak sen bağışlarsın. Katından bir bă̆ışlamayla beni bă̆ışla ve bana rahmet eyle! Zira muhakkak sen çok bağışlayıcı ve merhamet edicisin." 93

3. Hz. Ali'den rivâyet edildiğine göre Resûlullah (s.a.v.) teşehhüd ile selam arasında şu duayı yapard1:

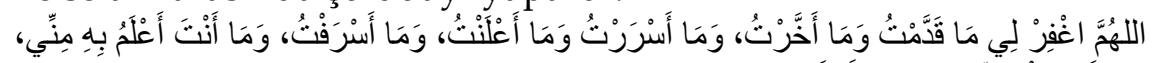

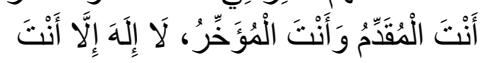

"Allah'ım! Takdim ettiğim, tehir ettiğim, gizli yaptı̆̆ım, alenî işlediğim ve aşırıya kaçtı̆̆ım günahlarımı benim için bağışla! Zira sen takdim ve tehir edensin ve senden başka ilah yoktur."94

91 Buhârî, "Ezân", 150; Müslim, "Salât", 16; Ebû Dâvûd, "Salât”, 177; Nesâî, "Sehv", 56; İbn Huzeyme, Sahîh, 1: 348.

92 Buhârî, “Ezân", 149; Müslim, "el-Mesâcid ve Mevâzıu's-salât", 129; Ebû Dâvûd, "Salât", 148; Nesâî, "Sehv", 64; Taberânî, el-Mu'cemu'l-evsat, 8: 330.

93 Buhârî, "Ezân”, 149; Tirmizî̀, “Deavât", 96; Nesâ̂̂, "Sehv", 59; İbn Mâce, "Dua", 2.

94 Müslim, "Salâtü'l-müsâfirîn ve Kasruhâ", 201; Ebû Dâvûd, "Salât", 118; Tirmizî, "Deavât", 32; İ̉n Huzeyme, Sahîh, 1: 358. 
250 | A. GÖZÜN / Namazdaki Dua Yerleriyle Şekillerinin Hadîslerle Tespiti ve Değerlendirilmesi

Zikredilen vb. rivâyetlerden Hz. Peygamber'in (s.a.v.) kade-i ahîrede farklı şekillerde dualar yaptığı ve ümmetini aynı yerde istedikleri herhangi bir duay1 ${ }^{95}$ yapmaya teşvik ettiği açıkça anlaşılmaktadır. Âlimlerin de ittifakıyla mezkûr yerde dua etmek sünnettendir.

\section{Sonuç}

İlgili kaynaklar üzerinden yapılan araştırmalar sonucunda namaz içerisinde Hz. Peygamber'in (s.a.v.) yedi yerde dua ettiği görülmektedir. $\mathrm{Bu}$ yerler kısaca şunlardır; kıyamın başı (istiftâh duası), kıyamın ortası (zamm-1 sûre okurken-vitirde kıyamın sonu), rükû, itidal (rükûdan kalkınca), secde, iki secde arası ve kade-i ahîrede selam öncesi.

Bununla birlikte fakîhler başta olmak üzere âlimler, tüm namazlarda $\mathrm{m} 1$ yoksa bütün namazlarda $\mathrm{m} 1$ mezkûr yerlerde dua edilebileceği hakkında ihtilaf etmişlerdir. Farz olsun nafile olsun bütün namazların kade-i ahîresinde selam vermeden önce dua etmenin sünnet olduğunda ittifak etmişlerdir. Diğer yerlerde ise farklı görüşlere sahip olmuşlardır.

Bazı âlimler nafile yahut gece namazı kaydı koymaksızın bütün namazlarda geri kalan altı yerde de dua etmenin caiz ve müstehab olduğunu ifade etmişlerdir. Diğer bir kısmı hem rükûda hem de secdede dua etmeyi, bazıları da sadece secdede dua etmeyi de bütün namazlarda müstehab görmüşlerdir. Özellikle Hanefîler başta olmak üzere bazı fakîhler ise mezkûr altı yerde dua etmeyi özellikle teheccüd namazı olmak üzere nafile namazlarla kayıtlamışlardır.

Ayrıca mezkûr yerlerde yapılacak dua sîgalarında ve şekillerinde de ihtilaf söz konusudur. Şöyle ki; ittifakla duanın sünnet olduğu kade-i ahîrede özellikle Hanefîlere ve Hanbelîlerin çoğunluğuna göre insanların sözlerine benzer dualarla dua edilmemesi gerekir. Ancak diğer âlimlere göre zikredilen yerde ve secdede Hz. Peygamber'in (s.a.v.) dua edilmesine dair emri serbestlik içerdiği için her türlü dua yapılabilir. Bu iki yerin dışında ise ancak me'sûr dualarla dua yapilabilir.

Sonuç olarak özellikle ülkemizde yaşayan Müslümanların çoğunun algıladığı ve teamül olarak uygulayageldiği gibi namaz

95 Bu dualardan önce okunan ve halk içinde kısaca "salli-bârik duaları" diye bilinen dualar ise çalışmanın kapsamına alınmamıştır. Çünkü bunlar teşehhüd duası gibi sabittir. 
içerisinde sünnet olan sadece selam vermeden önce birkaç dua yapmak değildir. Bilakis bazı mezheblere göre birtakım kayıtları bulunsa da çalışmada tespit edilen yedi yerin hepsinde dua etmek müstehabtır. Şu kadar var ki; bazı yerlerde me'sûr dualarla yetinilmesi gerekir. Zira bu yerlerde mutlaklık yoktur. Secde ve kade-i ahîre gibi diğer bazı yerlerde ise dua şekillerinde esneklik yahut serbestlik söz konusudur.

\section{Kaynakça}

Abdurrezzâk, Ebû Bekr b. Hemmâm b. Nâfi' el-Himyerî el-Yemânî esSan'ânî. el-Musannef. Thk. Habîburrahmân el-Azamî. 11 Cilt. Beyrut: el-Mektebü'l-islâmî, 1403.

Aynî, Ebû Muhammed Bedruddîn Mahmud b. Ahmed b. Musa elHanefî. el-Binâye şerhu'l-hidâye. 13 Cilt. Beyrut: Dâru'l-kütübi'lilmiyye, 1420/2000.

Aynî, Ebû Muhammed Bedruddîn Mahmud b. Ahmed b. Musa elAyintâbî. Umdetü'l-kârî şerhu Sahîhi'l-Buhârî. 25 Cilt. Beyrut: Dâru ihyâi't-tirâsi'l-arabî, ts.

Bâbertî, Ebû Abdillah Ekmelüddîn Muhammed b. Muhammed b. Mahmûd er-Rûmî. el-İnâyetü şerhu'l-Hidâye. 10 Cilt. Beyrut: Dâru'lfikr, ts.

Beyhakî, Ebû Bekir Ahmed b. Hüseyin b. Ali b. Musa el-Horasânî. esSünenü'l-kübrâ. Thk. Muhammed Abdulkâdir Atâ. 10 Cilt. Beyrut: Dâru'l-kütübi'l-ilmiyye, 1424/2003.

Bezzâr, Ebû Bekir Ahmed b. Amr b. Abdilhâlık el-Atekî. el-Müsned: elBahru'z-zehhâr. Thk. Mahfûzurrahmân Zeynüllah - Âdil b. Sa'd Sabrî Abdulhâlık eş-Şâfî̂. 18 Cilt. Medine: Mektebetü'l-ulûm ve'lhikem, 1988-2009.

Buhârî, Ebû Abdillah Muhammed b. İsmail b. İbrahim b. el-Muğîra. Sahîhu'l-Buhârî. 8 Cilt. İstanbul: Çağrı Yayınları., 1413/1992.

Cessâs, Ebû Bekr Ahmed b. Ali er-Râzî. Şerhu Muhtasari't-Tahâvî. Thk. İsmetüllah İnâyetüllah Muhammed - Sâid Bekdâş - Muhammed Ubeydullah Hân - Zeynep Muhammed Hasan Fellâte. 8 Cilt. b.y.: Dâru's-sirâc, 1431/2010.

Cevherî, Ebû Nasr İsmail b. Hammâd el-Fârâbî. es-Sthâh: Tâcu'l-luğa ve sihâhu'l-arabiyye. Thk. Ahmed Abdulğafûr Attâr. 6 Cilt. Beyrut: Dâru'l-ilm li'l-melâyîn, 1407/1987.

Dârekutnî, Ebü'l-Hasan Ali b. Ömer b. Ahmed el-Bağdâdî. Sünen. Thk. Şuayb el-Arnavut - Hasan Abdulmün'im Şelebî - Abdullatîf 
252 | A. GÖZÜN / Namazdaki Dua Yerleriyle Şekillerinin Hadîslerle Tespiti ve Değerlendirilmesi

Hirzullah - Ahmed Berhûm. 5 Cilt. Beyrut: Müessesetü'r-risâle, 1424/2004.

Dârimî, Ebû Muhammed Abdullah Abdurrahman. Sünenü'd-Dârimî. 2 Cilt. İstanbul: Çağrı Yayınları, 1413/1992.

Ebû Abdillah el-Mâlikî, Muhammed b. Ahmed b. Muhammed Uleyş. Menhu'l-Celîl şerhu Muhtasari Halîl. 5 Cilt. Beyrut: Dâru'l-fikr, 1409/1989.

Ebû Dâvûd, Süleyman b. Eş'as. Sünenü Eb̂̂ Dâvûd. 5 Cilt. İstanbul: Çağrı Yayınları, 1413/1992.

Ebû Yusuf, Yakub b. İbrahim b. Habîb el-Ensârî. el-Âsâr. Thk. Ebü'1-Vefâ el-Afganî. Beyrut: Dâru'l-kütübi'l-ilmiyye, ts.

Elbânî, Ebû Abdirrahmân Muhammed Nâsıruddîn b. el-Hâcc Nuh b. Necâtî b. Âdem. Sahîhu Ebî Dâvûd. 7 Cilt. Kuveyt: Müessesetü ğirâs, 1423/2002.

Elbânî, Ebû Abdirrahmân Muhammed Nâsıruddîn b. el-Hâc Nuh b. Necâtî b. Âdem. Silsiletü'l-ehâdîsi's-sahîha ve şey'un min fikhihâ ve fevâidihâ. 7 Cilt. Riyad: Mektebetü'l-maârif, 1415-1422/1995-2002.

Elbânî, Ebû Abdirrahmân Muhammed Nâsıruddîn b. el-Hâcc Nuh b. Necâtî b. Âdem. Zaîfu Eb̂̂ Dâvûd. 2 Cilt. Kuveyt: Müessesetü ğirâs, 1423.

Esyûbî, Muahmmed b. Ali b. Âdem b. Musa el-Vellevî. Zahîratü'l-ukbâ fî şerhi'l-Müctebâ. 42 Cilt. b.y.: Dâru'l-mirâc, 1416-1424/1996-2003.

Girnâtî, Ebû Abdillah el-Mevvâk Muhammed b. Yusuf b. Ebî Kâsım b.

Yusuf el-Abderî. et-Tâc ve'l-iklîl li Muhatasari Halîl. 8 Cilt. Beyrut: Dâru'l-kütübi'l-ilmiyye, 1416/1994.

Haccâvî, Ebu'n-Necâ Şerefüddîn Musa b. Ahmed b. Musa el-Makdisî. elİknâ' fî fikhi'l-İmam Ahmed b. Hanbel. Thk. Abdullatîf Muhammed Musa es-Sübkî. 4 Cilt. Beyrut: Dâru'l-ma'rife, ts.

Hâkim, Ebû Abdillah Muhammed b. Abdillah b. Muhammed enNeysâbûrî. el-Müstedrek. Thk. Mustafa Abdulkâdir Atâ. 4 Cilt. Beyrut: Dâru'l-kütübi'l-ilmiyye, 1411/1990.

Halvetî, Abdurrahmân b. Abdillah b. Ahmed el-Ba'lî. Keşfü'l-muhadderât ve'r-riyâzu'l-müzhirât li şerhi ahsari'l-muhtesarât. Thk. Muhammed b. Nâsır el-Acemî. 2 Cilt. Beyrut: Dâru'l-beşâiri'l-islâmiyye, 1423/2002.

Hattâbî, Ebû Süleyman Hamd b. Muhammed b. İbrahim el-Büstî. Meâlimü's-sünen. 4 Cilt. b.y.: el-Matbaatü'l-ilmiyye, 1351/1932. 
A. GÖZÜN / Determination and Evaluation of Praying Places and Forms in Prayer with Hadîths | 253

Humeydî, Ebû Bekr Abdullah b. Zübeyr b. İsa el-Kuraşî el-Esedî. Müsned. Thk. Hasan Selîm Esed ed-Dârânî. 2 Cilt. Dimaşk: Dârussikâ, 1996.

İbn Abdilberr, Ebû Ömer Yusuf b. Abdillah b. Muhammed el-Kurtubî. el-Kâfi fí fikhi ehli'l-Medîne. Thk. Muhammed Muhammed Ehyed. 2 Cilt. Riyad: Mektebetï'r-Riyad el-hadîse, 1400/1980.

İbn Battâl, Ebü'l-Hasan Ali b. Halef b. Abdilmelik. Şerhu Sahîhi'l-Buhârî. Thk. Ebû Temîm Yâsir b. İbrahim. 10 Cilt. Riyad: Mektebetü'rrüşd, 1423/2003.

İbn Ebî Hâtim, Ebû Muhammed Abdurrahman b. Muhammed b. İdris el-Hanzalî er-Râzî. el-Cerh ve'ta'dîl. 9 Cilt. Beyrut: Dâru ihyâi'ttürâsi'l-arabî, 1271/1952.

İbn Ebî Hâtim, Ebû Muhammed Abdurrahman b. Muhammed b. İdris el-Hanzalî er-Râzî. el-ïlel. Thk. Sa'd b. Abdillah el-Hamîd - Hâlid b. Abdirrahmân el-Cerîsî. 7 Cilt. Riyad: Matâbiu'l-Humeyzî, $1427 / 2006$.

İbn Ebî Şeybe, Ebû Bekr Abdullah b. Muhammed b. İbrahim el-Absî. elMusannef. Thk. Kemal Yusuf el-Hût. 7 Cilt. Riyad: Mektebetü'rrüşd, 1409.

İbn Hacer, Ebü'l-Fadl Ahmed b. Ali el-Askalânî. Fethu'l-Bârî şerhu Sahîhi'l-Buhârî. 13 Cilt. Beyrut: Dâru'l-ma'rife, 1379.

İbn Hibbân, Ebû Hâtim Muhammed b. Hibbân b. Ahmed ed-Dârimî elBüstî. Sahîh. Thk. Şuayb el-Arnavut. 18 Cilt. Beyrut: Müessesetü'rrisâle, 1414/1993.

İbn Huzeyme, Ebû Bekr Muhammed b. İshak en-Neysâbûrî. Sahîh. Thk. Muhammed Mustafa el-Azamî. 4 Cilt. Beyrut: el-Mektebü'l-islâmî, ts.

İbn Kayyim el-Cevziyye, Muhammed b. Ebî Bekr b. Eyyüb b. Sa'd. Şifâu'l-alîl fì mesâili'l-kazâi ve'l-kaderi ve'l-hikmeti ve't-ta'lîl. Beyrut: Dâru'l-ma' rife, 1398/1978.

İbn Kayyim el-Cevziyye, Şemsüddîn Muhammed b. Ebî Bekir b. Eyyüb. Zâdu'l-meâd fì hedyi hayri'l-ibâd. 5 Cilt. Beyrut: Müessesetü'r-risâle, 1415/1994.

İbn Kudâme, Ebû Muhammed Muvaffakuddîn Abdullah b. Ahmed b. Muhammed el-Cemâilî el-Makdisî. el-Kâfí fî fikhi'l-İmam Ahmed. 4 Cilt. Beyrut: Dâru'l-kütübi'l-ilmiyye, 1414/1994.

İbn Mâce, Ebû Abdillah Muhammed b. Yezîd. Sünenü İbn Mâce. 2 Cilt. İstanbul: Çağrı Yayınları, 1413/1992. 
254 | A. GÖZÜN / Namazdaki Dua Yerleriyle Şekillerinin Hadîslerle Tespiti ve Değerlendirilmesi İbn Manzûr, Ebü'l-Fadl Cemâlüddîn Muhammed b. Mükerrem b. Ali elEnsârî er-Ruveyfiî el-İfrîkî el-Misrî. "Slv". Lisânü'l-arab. 15 Cilt. Beyrut: Dâru Sâdir, 1414.

İbn Müflih, Ebû İshak Burhânüddîn İbrahim b. Muhammed b. Abdillah. el-Mubdi' fî şerhi'l-Mukni'. 8 Cilt. Beyrut: Dâru'l-kütübi'l-ilmiyye, 1418/1997.

İbn Receb el-Hanbelî, Zeynüddîn Abdurrahmân b. Ahmed el-Bağdâdî. Fethu'l-Bârî şerhu Sahîhi'l-Buhârî. Thk. Mahmud b. Şaban b. Abdilmaksûd - Mecdî b. Abdilhâlık eş-Şâfiî - İbrahim b. İsmail elKâdî. 8 Cilt. Medine: Mektebetü'l-ğurabâi'l-eseriyye, 1417/1996.

İbn Rüşd, Ebü'l-Velîd Muhammed b. Ahmed b. Muhammed b. Ahmed el-Kurtubî. Bidâyetü'l-müctehid ve nihâyetü'l-muktesid. 4 Cilt. Kahire: Dâru'l-hadîs, 1425/2004.

İbn Teymiyye, Ebü'l-Abbâs Takıyyüddîn Ahmed b. Abdilhalîm elHarrânî. Mecmû'u'l-fetâvâ. Thk. Abdurrahman b. Muhammed b. Kâsım. 35 Cilt. Medine: Mücemmeu'l-Melik Fehd, 1416/1995.

İbn Teymiyye, Ebü'l-Abbâs Takıyyüddîn Ahmed b. Abdilhalîm b. Abdisselâm el-Harrânî ed-Dimaşkî. Şerhu'l-Umde. Thk. Abdulazîz b. Ahmed el-Müşeykıh. Riyad: Dâru'l-âsıme, 1429/2008.

İbnü'l-Arabî, Ebû Bekir Kâdî Muhammed b. Abdillah el-Meâfirî el-İşbîlî. el-Mesâlik fì şerhi Muvattâ Mâlik. 8 Cilt. b.y.: Dâru'l-garbi'l-islâmî, $1428 / 2007$.

İbnü'l-Hâcib, Ebû Amr Cemâlüddîn Osman b. Ömer b. Ebî Bekir b. Yunus el-Kürdî el-Mâlikî. Câmiu'l-ümmehât. Thk. Ebû Abdirrahmân el-Ahdar el-Ahdarî. b.y.: el-Yemâme, 1421/2000.

İbnü'l-Mülakkın, Ebû Hafs Siracüddîn Ömer b. Ali b. Ahmed el-Misrî eş-Şâfîi. el-Bedru'l-münîr fî tahrîci'l-ehâdîsi ve'l-âsâri'l-vâkl'ati fi'şşerhil-kebîr. Thk. Mustafa Ebü'l-ğayt - Abdullah b. Süleyman - Yâsir b. Kemal. 9 Cilt. Riyad: Dâru'l-hicret, 1425/2004.

İbnü'n-Nakîb, Ebü'l-Abbâs Şihâbüddîn Ahmed b. Lü'lü' b. Abdillah erRûmî. Umdetü's-sâlik ve uddetü'n-nâsik. Katar: eş-Şuûnü'd-dîniyye, 1982.

İmrânî, Ebü'l-Hüseyin Yahya b. Ebi'l-hayr b. Sâlim el-Yemenî. el-Beyân fî mezhebi'l-İmam eş-Şâfiî. Thk. Kâsım Muhammed en-Nûrî. 13 Cilt. Cidde: Dâru'l-minhâc, 1421/2000, 2: 225.

Karâfî, Ebü'l-Abbâs Şihâbüddîn Ahmed b. İdris b. Abdirrahmân elMâlikî. ez-Zehîra. Thk. Muhammed Hacı - Saîd Ârâb - Muhammed Ebû Hubze. 14 Cilt. Beyrut: Dâru'l-ğarbi'l-islâmî, 1994. 
A. GÖZÜN / Determination and Evaluation of Praying Places and Forms in Prayer with Hadîths | 255

Kâsânî, Alâuddîn Ebû Bekr b. Mes'ûd b. Ahmed. Bedâyiu's-sanâyi' fî tertîbi'ş-şerâyi'. 7 Cilt. Beyrut: Dâru'l-kütübi'l-ilmiyye, 1406/1986.

Lahmî, Ebü'l-Hasan Ali b. Muhammed er-Rib'î et-Tebsıra. Thk. Ahmed Abdulkerî Necîb. 14 Cilt. Katar: Vizâratü'l-evkâf ve'ş-şuûni'lislâmiyye, 1432/2011.

Malatî, Ebü'l-Mehâsin Cemâlüddîn Yusuf b. Musa b. Muhammed. elMu'tasar mine'l-muhtasar min müşkili'l-âsâr. 2 Cilt. Beyrut: Âlemü'lkütüb, ts.

Mâlik b. Enes. el-Muvattâ. 2 Cilt. İstanbul: Çağrı Yayınları, 1413/1992.

Mâlik b. Enes b. Mâlik b. Âmir el-Esbahî el-Medenî. el-Müdevvene. 4 Cilt. Beyrut: Dâru'l-kütübi'l-ilmiyye, 1451/1994.

Mâzerî, Ebû Abdillah Muhammed b. Ali b. Ömer et-Temîmî el-Mâlikî. Şerhu't-telkîn. Thk. Muhammed Muhtar es-Selâmî. 5 Cilt. Dâru'lğarbi'l-islâmî, 2008.

Mehdivî, Ebü't-Tâhir İbrahim b. Abdissamed b. Beşîr et-Tenûhî. etTenbîh alâ mebâdii't-tevcîh. Thk. Muhammed Belhasân. 2 Cilt. Beyrut: Dâru İbn Hazm, 1428/2007.

Merdâvî, Ebü'l-Hasan Alâuddîn Ali b. Süleyman ed-Dımaşkî. el-İnsâf fî ma'rifeti'r-râcihi mine'l-hilâf. 12 Cilt. b.y.: Dâru ihyâi't-türâsi'l-arabî, ts.

Moğoltay, Ebû Abdillah Alâuddîn Moğoltay b. Kılıç b. Abdillah elBekcerî el-Misrî. Şerhu Süneni İbn Mâce: el-I'lâm bi sünnetihi aleyhi'sselâm. Thk. Kâmil Uveyda. 5 Cilt. Suûdiyye: Mektebetü Nizâr Mustafa el-Bâz. 1419/1999.

Müslim, Ebü'l-Hüseyin Müslim b. el-Haccâc. Sahîhu Müslim. 3 Cilt. İstanbul: Çağrı Yayınları, 1413/1992.

Nesâî, Ebû Abdirrahman Ahmed b. Şuayb b. Ali el-Horasânî. Sünenü'nNesâ̂i. 8 Cilt. İstanbul: Çağrı Yayınları, 1413/1992.

Nevevî, Ebû Zekeriyya Muhyiddîn Yahya b. Şeref. el-Mecmû şerhu'lMühezzeb. 20 Cilt. Beyrut: Dâru'l-fikr, ts.

Nevevî, Ebû Zekeriyya Muhyiddîn Yahya b. Şeref. Ravzatü't-tâlibîn ve umdetü'l-müftîn. Thk. Züheyr eş-Şâvîş. 12 Cilt. Beyrut: elMektebü'l-islâmî, 1412/1991.

Râfiî, Ebü'l-Kâsım Abdulkerîm b. Muhammed b. Abdilkerîm el-Kazvînî. el-Azîz şerhu'l-Vecîz:eş-Şerhu'l-kebîr. Thk. Ali Muhammed Ivaz Âdil Ahmed Abdulmevcûd. 13 Cilt. Beyrut: Dâru'l-kütübi'lilmiyye, 1417/1997. 
256 | A. GÖZÜN / Namazdaki Dua Yerleriyle Şekillerinin Hadîslerle Tespiti ve Değerlendirilmesi

Ramlî, Şemsüddîn Muhammed b. Ebi'l-Abbâs Ahmed. Nihâyetü'l-muhtâc ilâ şerhi'l-Minhâc. 8 Cilt. Beyrut: Dâru'l-fikr, 1404/1984.

Ruaynî, Ebû Abdillah Şemsüddîn Muhammed b. Muhammed b.

Abdirrahmân el-Hattâb. Mevâhibü'l-celîl fî şerhi Muhtasari Halîl. 6 Cilt. b.y.: Dâru'l-fikr, 1412/1992.

Rûyânî, Ebü'l-Mehâsin Abdulvâhid b. İsmail. Bahru'l-mezheb. Thk. Târık Fethî. 14 Cilt. Beyrut: Dâru'l-kütübi'l-ilmiyye, 2009.

Sadruddîn, Ali b. Ali b. Ebi'l-İzz el-Hanefî. et-Tenbîh alâ müşkilâti'lHidâye. Thk. Abdulhakîm b. Muhammed Şâkir - Enver Salih Ebû Zeyd. 5 Cilt. Suûdiyye: Mektebetü'r-rüşd, 1424/2003.

Sa'lebî, Ebû Muhammed Abdulvehhâb b. Ali b. Nasr el-Bağdâdî elMâlikî. el-Me'ûne alâ mezhebi âlimi'l-Medîne. Thk. Humeyş Abdulhakk. 3 Cilt. Mekke: el-Mektebetü't-ticâriyye, ts.

Sehârenpûrî, Halîl Ahmed. Bezlü'l-mechûd fî halli Süneni Ebî Dâvîd. 14 Cilt. Hindistan: Merkezü'ş-Şeyh Ebi'l-Hasan en-Nedvî li'l-buhûs ve'd-dirâsâti'l-islâmiyye, 1427/2006.

Semerkandî, Ebû Bekr Alâuddîn Muhammed b. Ahmed b. Ebî Ahmed. Tuhfetü'l-fukahâ. 3 Cilt. Beyrut: Dâru'l-kütübi'l-ilmiyye, 1414/1994.

Serahsî, Şemsü'l-eimme Muhammed b. Ahmed b. Ebî Sehl. el-Mebsût, 30 Cilt. Beyrut: Dâru'l-ma'rife, 1414/1993.

Süneykî, Ebû Yahya Zekeriyya b. Muhammed b. Ahmed b. Zekeriyya elEnsârî. Fethu'l-vehhâb bi şerhi Menheci't-tullâb. 2 Cilt. Beyrut: Dâru'1fikr, 1414/1994.

Şâfiî, Ebû Abdillah Muhammed b. İdris el-Kuraşî. Müsned. Beyrut: Dâru'l-kütübi'l-ilmiyye, 1400.

Şâfî̂, Ebû Abdillah Muhammed b. İdris el-Kuraşî. el-Ümm. 8 Cilt. Beyrut: Dâru'l-ma'rife, 1410/1990.

Şevkânî, Muhammed b. Ali b. Muhammed b. Abdillah el-Yemenî. Neylü'l-evtâr. Thk. Isâmüddîn es-Sabâbatî. 8 Cilt. Misır: Dâru'1hadîs, 1413/1993.

Şeybânî, Ebû Abdillah Ahmed b. Muhammed b. Hanbel. Müsned. 6 Cilt. İstanbul: Çağrı Yayınları., 1413/1992.

Şeybânî, Ebû Abdillah Muhammed b. Hasan. el-Âsâr. Thk. Ebü'l-vefâ elAfganî. 2 Cilt. Beyrut: Dâru'l-kütübi'l-ilmiyye, ts.

Şeybânî, Ebû Abdillah Muhammed b. Hasan b. Ferkad. el-Asl:el-Mebsût. Thk. Ebü'l-vefâ el-Afganî. 5 Cilt. Karaçi: İdâretü'l-Kur'ân ve'1ulûmi'l-islâmiyye, ts. 
A. GÖZÜN / Determination and Evaluation of Praying Places and Forms in Prayer with Hadîths | 257

Şirbînî, Şemsüddîn Muhammed b. Ahmed el-Hatîb. Muğni'l-muhtâc ilâ ma'rifeti meânî elfâzi'l-Minhâc. 6 Cilt. Beyrut: Dâru'l-kütübi'lilmiyye, 1415/1994.

Taberânî, Ebü'l-Kâsım Süleyman b. Ahmed b. Eyyüb el-Lahmî eş-Şâmî. ed-Duâ. Thk. Mustafa Abdulkâdir Atâ. Beyrut: Dâru'l-kütübi'lilmiyye, 1413.

Taberânî, Ebü'l-Kâsım Süleyman b. Ahmed b. Eyyüb el-Lahmî. elMu'cemu'l-evsat. Thk. Târık b. Ivazıllah b. MuhammedAbdulmuhsin b. İbrahim el-Hüseynî. 10 Cilt. Kahire: Dâru'lharemeyn, ts.

Taberânî, Ebü'l-Kâsım Süleyman b. Ahmed b. Eyyüb el-Lahmî eş-Şâmî. el-Mu'cemu'l-kebîr. Thk. Hamdî b. Abdilmecîd es-Selefî. 25 Cilt. Kahire: Mektebetü İbn Teymiyye, 1415/1994.

Tahâvî, Ebû Cafer Ahmed b. Muhammed b. Selâme el-Ezdî el-Misrî. Şerhu meâni'l-âsâr. Thk. Muhammed Zührî en-Neccâr Muhammed Seyyid Câdü'l-hakk. 5 Cilt. Âlemü'l-kütüb, 1414/1994.

Tahtâvî, Ahmed b. Muhammed b. İsmail el-Hanefî. Hâşiyetü't-Tahtâvî alâ Merâkı'l-felâh. Thk. Muhammed Abdulazîz el-Hâlidî. Beyrut: Dâru'l-kütübi'l-ilmiyye, 1418/1997.

Tayâlisî, Ebû Dâvûd Süleyman b. Dâvûd b. Cârûd el-Basrî. Müsned. Thk. Muhammed b. Abdilmuhsin et-Türkî. 4 Cilt. Misır: Dâru Hecer, 1419/1999.

Tebrîzî, Ebû Abdillah Veliyyüddîn Muhammed b. Abdillah el-Hatîb elÖmerî. Mişkâtü'l-mesâbîh. Thk. Muhammed Nâsıruddîn el-Elbânî. 3 Cilt. Beyrut: el-Mektebü'l-islâmî, 1985.

Tirmizî, Ebû İsa Muhammed b. İsa b. Sevra. Sünenü't-Tirmizî. 5 Cilt. İstanbul: Çağrı Yayınları., 1413/1992.

Zebîdî, Ebü'l-Feyz Mürtezâ Muhammed b. Muhammed b. Abdirrezzâk el-Hüseynî. "Slv". Tâcu'l-arûs min cevâhiri'l-kâmûs. 40 Cilt. Dâru'lhidâye, ts.

Zerkeşî, Şemsüddîn Muhammed b. Abdillah el-Misrî el-Hanbelî. Şerhu'z-Zerkeşî alâ Muhatasari'l-Hırakî. 7 Cilt. Dâru'l-Ubeykân, 1413/1993.

Zeylaî, Fahruddîn Osman b. Ali b. Mihcen el-Bârî̂. Tebyînü'l-hakâyik şerhu Kenzi'd-dekâyik. 6 Cilt. Bulak: el-Matba'atü'l-kübra'l-emîriyye, 1313. 